\title{
Hemispheric transport and influence of meteorology on global aerosol climatology
}

\author{
T. L. Zhao ${ }^{1}$, S. L. Gong ${ }^{2,3}$, P. Huang ${ }^{2}$, and D. Lavoué ${ }^{4}$ \\ ${ }^{1}$ Key Lab of Atmospheric Physics and Environment, CMA Nanjing University of Information Science \& Technology \\ Nanjing, Jiangsu, 210044, China \\ ${ }^{2}$ Air Quality Research Division, Science \& Technology Branch, Environment Canada, 4905 Dufferin Street, Toronto, Ontario \\ M3H 5T4, Canada \\ ${ }^{3}$ Chinese Academy of Meteorological Sciences China Meteorological Administration (CMA), Beijing 100081, China \\ ${ }^{4}$ DL Modeling \& Research, Brampton, Ontario, Canada
}

Correspondence to: S. L. Gong (sunling.gong@ec.gc.ca)

Received: 1 December 2011 - Published in Atmos. Chem. Phys. Discuss.: 20 April 2012

Revised: 3 August 2012 - Accepted: 6 August 2012 - Published: 22 August 2012

\begin{abstract}
Based on a 10-yr simulation with the global air quality modeling system GEM-AQ/EC, the northern hemispheric aerosol transport with the inter-annual and seasonal variability as well as the mean climate was investigated. The intercontinental aerosol transport is predominant in the zonal direction from west to east with the ranges of interannual variability between $14 \%$ and $63 \%$, and is $0.5-2$ orders of magnitude weaker in the meridional direction but with larger inter-annual variability. The aerosol transport is found to fluctuate seasonally with a factor of 5-8 between the maximum in late winter and spring and the minimum in late summer and fall. Three meteorological factors controlling the intercontinental aerosol transport and its interannual variations are identified from the modeling results: (1) Anomalies in the mid-latitude westerlies in the troposphere. (2) Variations of precipitation over the intercontinental transport pathways and (3) Changes of meteorological conditions within the boundary layer. Changed only by the meteorology, the aerosol column loadings in the free troposphere over the source regions of Europe, North America, South and East Asia vary inter-annually with the highest magnitudes of 30-37\% in January and December and the lowest magnitudes of 16-20\% in August and September, and the interannual aerosol variability within the boundary layer influencing the surface concentrations with the magnitudes from $6 \%$ to $20 \%$ is more region-dependent. As the strongest climatic signal, the El Niño-Southern Oscillation (ENSO) can lead the anomalies in the intercontinental aerosols in El Niño- and La
\end{abstract}

Niña-years respectively with the strong and weak transport of the mid-latitude westerlies and the low latitude easterlies in the Northern Hemisphere (NH).

\section{Introduction}

Intercontinental transport of air pollution has been identified by a wealth of evidence observed from the ground, aircraft and satellites (HTAP, 2010). There is a growing international concern on the problem of long-range air pollutant transport. Although a lot of studies have revealed the transpacific transport of Asian pollution to North America (Jaffe et al., 1999; Wilkening et al., 2000; VanCuren, 2003), the transatlantic transport of North American pollution to Europe (Li et al., 2002; Parrish et al., 1993) and the transeurasian transport of European pollution to Asia (Huang et al., 2007; Chin et al., 2007) in the NH, the magnitude and variability of intercontinental air pollution transport in air quality control strategies are still an issue for exploration. To obtain a better understanding of hemispheric transport of air pollutants in the NH and provide estimates of source-receptor (S$\mathrm{R})$ relationships for intercontinental air pollution, the Task Force on Hemispheric Transport of Air Pollution (TF HTAP) (http:www.htap.org) was established under the United Nations Economic Commission for Europe (UNECE) Convention on Long Range Transboundary Air Pollution (LRTAP). Aerosol, also known as particulate matter (PM) in the air 
quality research community, is one of major air pollutants determining ambient air quality. In addition, the impacts of aerosols on climate, ecosystem and biogeochemical cycles have been well recognized (IPCC, 2007).

The S-R relationship describes the impacts of emissions from an upwind source region to pollutant concentrations or deposition at a downwind receptor location (Seibert and Frank, 2004). Intercontinental transport of S-R air pollution is complicated by several factors. Generally, the factors controlling the S-R relationships for intercontinental aerosol transport could be separated into two types: emission and meteorology (Voulgarakis et al., 2010; Gong et al., 2010). The emission factor includes the source emission strength, chemical transformation and production; the meteorological factor determines the transport pathway from the source to receptor regions, exchanges between boundary layer and free troposphere, the removal processes occurring over the source and receptor regions as well as along the transport pathways. The emissions of air pollutants in many source regions of the NH have changed during the last few decades. For example, in East Asia, an increase of anthropogenic aerosols has accompanied the rapid industrial development and high population density (Zhang et al., 2008). In West Europe and North America, a generally reducing trend of aerosol emissions from industry and transport sectors has been caused by the environmental protection strategies (van der Werf et al., 2006; Gong et al., 2010). In South Asia, anthropogenic and biomass burnings are one of the important sources of "atmospheric brown cloud" (Ramanathan and Crutzen, 2003). Governed by atmospheric circulations, air pollutants could be transported from the source to receptor regions in a hemispheric or global scale. Due to significant anomalies of the atmospheric circulations and other meteorological variables from year to year, the importance of meteorological factor can be investigated by driving the observed inter-annual variability in the S-R relationships influencing the ambient air quality.

The S-R relationships on intercontinental scale for transpacific transport of air pollutions from East Asia to North America (Jaffe et al., 2003; Liu et al., 2005; Liu et al., 2008; Zhao et al., 2008), transatlantic transport from North America to Europe (Creilson et al., 2003; Stohl and Eckhardt, 2004; Stohl et al., 2002b) and from African deserts to North America (Schepanski et al., 2009; Prospero et al., 2002) have been intensively assessed for specific air pollutants during a certain period or some emission episodes. For mid-latitude/Arctic transport, Eckhardt et al. (2003) predicted that during positive phases of the North Atlantic Oscillation (NAO) surface concentrations of tracers in the Arctic winter were elevated by about $70 \%$ relative to negative phases of the NAO. Consistent with that prediction, Sharma et al. (2006) found that observed BC at Alert in the Canadian High Arctic was $40 \%$ higher during the positive phase of the NAO. However, a recent study (Osborn, 2006) found no significant trends in NAO from 1981 to 2005, which exerts a sig-
Table 1. Definition of four regions in the Northern Hemisphere for the HTAP-study (http://www.htap.org).

\begin{tabular}{lll}
\hline Region & Longitude & Latitude \\
\hline SA: South Asia & $50^{\circ} \mathrm{E}-95^{\circ} \mathrm{E}$ & $5^{\circ} \mathrm{N}-35^{\circ} \mathrm{N}$ \\
EA: East Asia & $95^{\circ} \mathrm{E}-160^{\circ} \mathrm{E}$ & $15^{\circ} \mathrm{N}-50^{\circ} \mathrm{N}$ \\
EU: Europe + North Africa & $10^{\circ} \mathrm{W}-50^{\circ} \mathrm{E}$ & $25^{\circ} \mathrm{N}-65^{\circ} \mathrm{N}$ \\
NA: North America & $125^{\circ} \mathrm{W}-60^{\circ} \mathrm{W}$ & $15^{\circ} \mathrm{N}-55^{\circ} \mathrm{N}$ \\
\hline
\end{tabular}

nificant control on pollutant transport to the Arctic. The NAO exhibits a less influence on the interannual variability of midlatitude/Arctic transport (Gong et al., 2010) and in transpacific transport (Liu et al., 2005). Under the framework of HTAP, the multiple model experiments were set up to examine the S-R relationships among four HTAP regions, roughly representing Europe (EU), North America (NA), East Asia (EA) and South Asia (SA) (Table 1). A set of emission perturbation experiments with year 2001 meteorology was performed with the multiple models in the TF HTAP assessment (HTAP, 2010) to estimate how emission changes in one HTAP region impact air quality in other HTAP-regions. A description of the multi-model experiments and key findings are published in the interim report from HTAP (2010) and a series of published papers based on the HTAP-dataset (Liu et al., 2009; Shindell et al., 2008; Wu et al., 2009; Fiore 2009; Sanderson et al., 2008; Anenberg et al., 2009). However, air pollution in the four HTAP regions and the intercontinental transport exhibits strong variations from year to year, which is resulted from a combination of changing emissions and meteorological conditions. The inter-annual variability at receptor sites is controlled by not only the tempospatial changes of emission sources but also the variations of atmospheric circulations or weather and climate patterns over the S-R regions and the transport pathways. This complicated feature is difficult to characterize from observations. To quantify the overall importance of hemispheric transport for aerosols, a single year simulation cannot evaluate the influence of inter-annual variability in meteorology on the S$\mathrm{R}$ relationships via changes in the intercontinental transport pathways for the HTAP. Characterizing this inter-annual variability is still a major challenge in an assessment of the S-R relationships for the HTAP.

Based on a 10-yr simulation of global aerosols from both natural and anthropogenic sources including as principal components of sulfate, organic carbon, black (elemental) carbon, soil dust and sea salt, the intercontinental aerosol transport was characterized in respect of the seasonal variations, the inter-annual variability and the mean climate for the HTAP (in Sect. 3). The anthropogenic aerosols were simulated with the constant emissions of global anthropogenic aerosols without any inter-annual changes during 19952004, and the inter-annual variability in the simulations was caused only by meteorological variations. Therefore, the 
meteorological influences on the inter-annual variability in aerosol transport could be investigated by using the anthropogenic aerosol simulation results (in Sect. 4). Additionally, the basic model features, aerosol emissions and experiment set-up are briefly described in Sect. 2, and this aerosol model study for the hemispheric aerosol transport is summarized and discussed in Sect. 5.

\section{Methodology}

Full details of the development and evaluation of GEMAQ/EC are given by Gong et al. (2012). This section briefly reviews the key components of the modelling system. The host meteorological model is the Global Environmental Multiscale (GEM) model developed by the Meteorological Service of Canada (MSC) for operational weather prediction (Côté et al., 1998). The model system GEM-AQ/EC is an integration of a gas phase chemistry module (ADOM) (Venkatram et al., 1988) and an aerosol module (CAM) (Gong et al., 2003a) into the GEM. The aerosol module CAM considers all of the atmospheric aerosol processes: production, transport, growth, coagulation, dry and wet deposition for five mixed aerosols of soil dust, sulphate, sea-salt, organic and black carbon in 12 aerosol size (diameter) bins from 0.01 to $40.96 \mu \mathrm{m}$, and an explicit microphysical cloud module to treat aerosol-cloud interactions only with wet deposition in clouds and below clouds but without effects of aerosols on precipitation. The chemical and aerosol modules are coupled in the host meteorological model "online". The GEM$\mathrm{AQ} / \mathrm{EC}$ is designed to provide a consistent framework between the meteorological and air quality aspects of the atmospheric system.

For the GEM-AQ/EC modeling, the emissions of soil dust and sea salt are on-line calculated with their emission parameterizations on basis of the current understanding on the physical processes involved in the wind forced movement of sea salt and soil dust particles (Gong et al., 1997, 2003b). The global sulphur emissions, including $\mathrm{SO}_{2}$, DMS and particulate sulphate, are based on the data of Global Emissions Inventory Activity (GEIA) (Olivier et al., 1996). The monthly emission-data of organic and black carbon are separated into the natural and anthropogenic sources. The natural emissions by boreal and temperate fires are changed from year to year, while the monthly anthropogenic emissions by fossil fuel and biomass burning of tropical forest fires, savannah fires are constant without any inter-annual changes over 1995-2004 (Gong et al., 2012).

The model evaluations prove the GEM-AQ provided satisfactory simulations of spatial and temporal distributions of global aerosols for a modeled climatology of aerosol transport. In this paper, the focus of study is placed on characterizing a mean climate of intercontinental aerosol transport in the $\mathrm{NH}$ and identifying the meteorological influence on inter-annual variability in the aerosol transport by using the

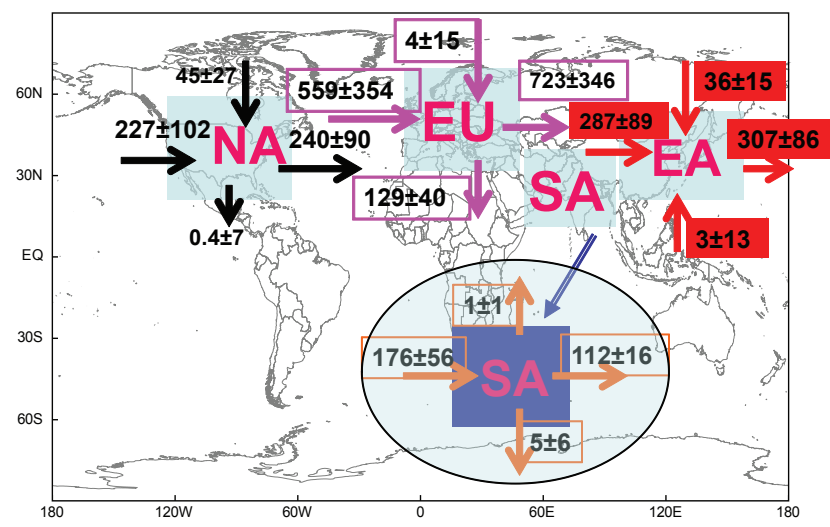

Fig. 1. Annual net mass $\left(\mathrm{Tg} \mathrm{d}^{-1}\right)$ of aerosols transported through the borders of four HTAP regions with the transport directions following the arrows, the mean values and the standard deviations over the $10-\mathrm{yr}$ of $1995-2004$.

10-yr modeling data. The aerosol transport is based on the analyses of aerosol transport flux and mass. The transport flux is calculated by multiplying aerosol concentrations with the zonal and meridional wind velocity components, and the transport mass of aerosols is obtained by an integral of transport flux over the areas of vertical cross section and the time step length in the model. Positive and negative components of aerosol transport flux or mass indicate respectively eastward and westward transport in zonal direction or northward and southward transport in meridional direction depending on the directions of wind velocity components. As a vector variable, transport flux and mass are also used to estimate the amount and direction of aerosol transport for the HTAP in the following sections.

\section{Mean climate of hemispheric aerosol transport}

Aerosols are one of major air pollutants determining ambient air quality and engaging in the HTAP. To more comprehensively present the mean climate of aerosol transport, we analyzed the transport flux and mass for all simulated aerosols of sulfate, soil dust and sea salt as well as organic carbon and black carbon from both natural and anthropogenic emission sources in the model in this section. A mean climate with the seasonal and inter-annual variability of the aerosol transport as well as the hemispheric transport patterns in the $\mathrm{NH}$ was constructed based on the 10-yr GEM-AQ/EC modeling as follows.

\subsection{Inter-annual variability}

Figure 1 shows the mean annual net mass of aerosols transported through the vertical sections at all borders of HTAP regions from surface up to the model top of $30 \mathrm{~km}$ with the transport directions following the arrows, the mean and the standard deviations over the $10 \mathrm{yr}$. Since the EA-, NA- and 
Table 2. The coefficients (\%) of variations in annual transport mass of total aerosols across the borders of four HTAP-regions over 19952004.

\begin{tabular}{lcccc}
\hline & EA-Region & NA-Region & EU-Region & SA-Region \\
\hline Western Border & 31 & 45 & 63 & 32 \\
Eastern Border & 28 & 37 & 48 & 14 \\
Southern Border & 433 & 1750 & 32 & 120 \\
Northern Border & 42 & 60 & 375 & 100 \\
\hline
\end{tabular}

EU- regions are mostly located in the mid-latitudes, it could be expected that the intercontinental transport over the EA-, NA- and EU- regions is dominated in the eastward direction along the mid-latitude westerly belt for the whole year. It is shown from the annual net aerosol transport mass in the 10-yr mean (Fig. 1) that for all the EA-, NA- and EU- regions, the zonal aerosol transport through the western and eastern borders is $0.5-2$ orders of magnitude stronger than the meridional transport from the northern and southern borders, and the aerosol exports across their eastern borders of these sources provide the largest transport mass to the downwind receptor regions. Although the large part of SAregion is situated in the tropics and subtropics, the South Asian monsoon wind flows and the effects of Tibetan Plateau on the tropospheric circulation result in a strong eastward transport across the SA-region with the weak southward and northward aerosol exports in the annual mean. Comparing to three mid-latitude EA, NA and EU-regions, the zonal transboundary transport across the SA-region is 2-4 times weaker, and aerosol could be also exported through the southern SA-border into the Indian Ocean for a long range transport (Lelieveld, 2001). Based on the annual net transport masses shown in Fig. 1, EU is the only "exporting" region of aerosols, and its export mass at the eastern boundary is more than two times greater compared to that of EA, and more than 2.5 times greater than that of NA. There could be two reasons for this: i.e. aerosol emissions and meteorology. As described in Gong et al. (2012), the global sulphur emissions are based on the data of Global Emissions Inventory Activity (GEIA), and climatological emissions representative of the end of 1980's were considered for the tropical forest fires and savannah fires in the modeling study. The EU-boundaries of $25^{\circ} \mathrm{N}$ to $65^{\circ} \mathrm{N}$ are mostly located in the mid-latitudes compared to the EA- and NA- boundaries (Table 1). As shown in Fig. $7 \mathrm{a}$ and $\mathrm{b}$, the mid-latitude westerlies prevail in the eastern EU boundary from summer to winter with the strongest aerosol export, while aerosols are imported by the easterlies in the low-latitudes of EA- and NA- boundaries with reducing the aerosol export mass at the EA- and NA- boundaries.

The coefficients of variations (CV) in aerosol transport across four HTAP-regions in Table 2 are defined as the ratio of the standard deviation to its mean in Fig. 1. The CV-values in Table 2 reflect the relative magnitudes of inter-annual variability in the hemispheric transport of aerosols for the HTAP-

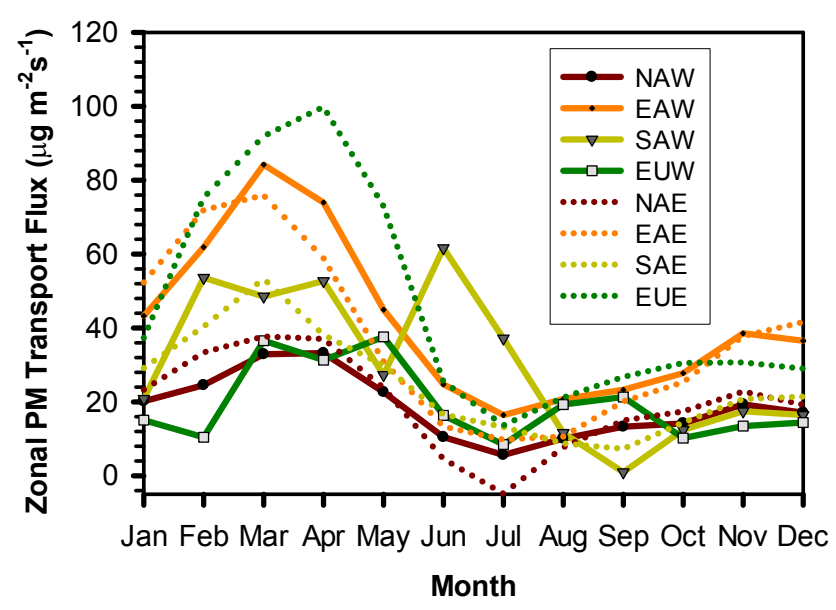

Fig. 2. Monthly variations of zonal aerosol transport fluxes $\left(\mu \mathrm{g} \mathrm{m}^{-2} \mathrm{~s}^{-1}\right)$ averaged in the vertical sections at the western and eastern borders of HTAP-regions over 1995-2004. NAW (NAE), EAW (EAE), EUW (EUE) and SAW (SAE) respectively stand for the western (eastern) borders of NA, EA, EU and SA regions.

regionally averaged variability and the S-R relationships over the HTAP-regions. Resulted from the inter-annual variability in both factors of emission and meteorology, the zonal transport across the EA-, NA- and EU-regions exhibits the significant inter-annual variability with a CV-range from $14 \%$ to $63 \%$, and the meridional transport experiences the larger inter-annual variability with the CV from $32 \%$ to $1750 \%$, although the meridional aerosol transport strengths are much weaker than the zonal transport, as shown with the mean values in Fig. 1. The higher CV-values in aerosol transport mass at the northern and southern borders of HTAP-regions are caused by large interannul anomalies in meridional wind over those borders due to the interactions of atmospheric circulations between the mid-latitudes and the Arctic region or between the mid- and low latitudes. This may also be linked to the larger eddy transport of the meridional circulation.

\subsection{Seasonal variations}

Due to the dominant transport components in the zonal direction for the hemispheric aerosol transport as shown in Fig. 1, we present monthly changes of the zonal aerosol transport fluxes averaged in the vertical section at the western and 
eastern borders of HTAP-regions in Fig. 2 for the seasonal variations in the aerosol transport. The intercontinental transport of aerosols across the NA-, EA-, SA- and EU-regions is found to vary seasonally with a factor of 5-8 between the maximum in late winter and spring (particularly in March and April) and the minimum in late summer and fall (particularly in July and September) (Fig. 2). As presented in Gong et al. (2012), the natural and anthropogenic aerosol emissions have a pronounced seasonality. The natural aerosol emissions seasonally vary with the seasonal cycles in meteorology and other eco-environments, and the variations of anthropogenic aerosol emissions rely on the seasonal changes of human activity. It is also confirmed from a 4-yr satellite-based assessment of transpacific transport of pollution aerosol that the pollution fluxes are largest in spring and smallest in summer(Yu et al., 2008). The strong seasonality of aerosol transport is caused from a combination of seasonal variations in atmospheric circulations and aerosol emissions in the HTAPregions. Additionally, a second maximal import of aerosol through the western border of SA-region in June (Fig. 2, SAW) is driven by the southwest jet of South Asian summer monsoon (Ding, 1994). Even though the seasonal variations in the aerosol transport are appreciable, the monthly transboundary aerosol transport across the western and eastern borders of HTAP-regions persists in the eastward direction during all seasons but for the eastern border of NA-region in July. At the eastern border of NA-region, the positive transport fluxes drop to a negative transport flux in July (Fig. 2). It means that North American aerosol transport reverses from a net outflow into the Atlantic to a net aerosol inflow into the NA-region in July, which is resulted from the strong westward transatlantic transport of Saharan dust aerosol into the NA-region by the easterly jet in summer (Jones et al., 2003).

To further illustrate the seasonal variations of transboundary aerosol transport across four HTAP-regions, the aerosol transport fluxes were seasonally averaged for winter (December, January and February) and summer (June, July and August) over $10 \mathrm{yr}$ of $1995-2004$. Figures 3-6 present the vertical cross sections of the winter and summer averaged transport fluxes at the western and eastern borders of four HTAP-regions. Over the NA-region, the aerosol import (export) flows at the western (eastern) border prevail in the midlatitude troposphere with the maximal centers at a height of about $10 \mathrm{~km}$ shifting from $40^{\circ} \mathrm{N}$ in winter to $50^{\circ} \mathrm{N}$ in summer (Fig. 3a and b). Associated with the seasonal changes of easterly jet in the low-latitudes $\left(15-30^{\circ} \mathrm{N}\right)$, the aerosol export from the NA-region across the western border into Pacific (Fig. 3a) and the aerosol import at the eastern border from Atlantic into the NA-region (Fig. 3b) vary from weak flows through a small section within the lower troposphere in winter to strong flows through a big section high to the upper troposphere in summer (Fig. 3a and b). The area of the strong aerosol import at the eastern border of NA-region extends northwards to more than $30^{\circ} \mathrm{N}$ in summer, confirming that a net aerosol inflow into the NA-region from the eastern a) Western NA-Border
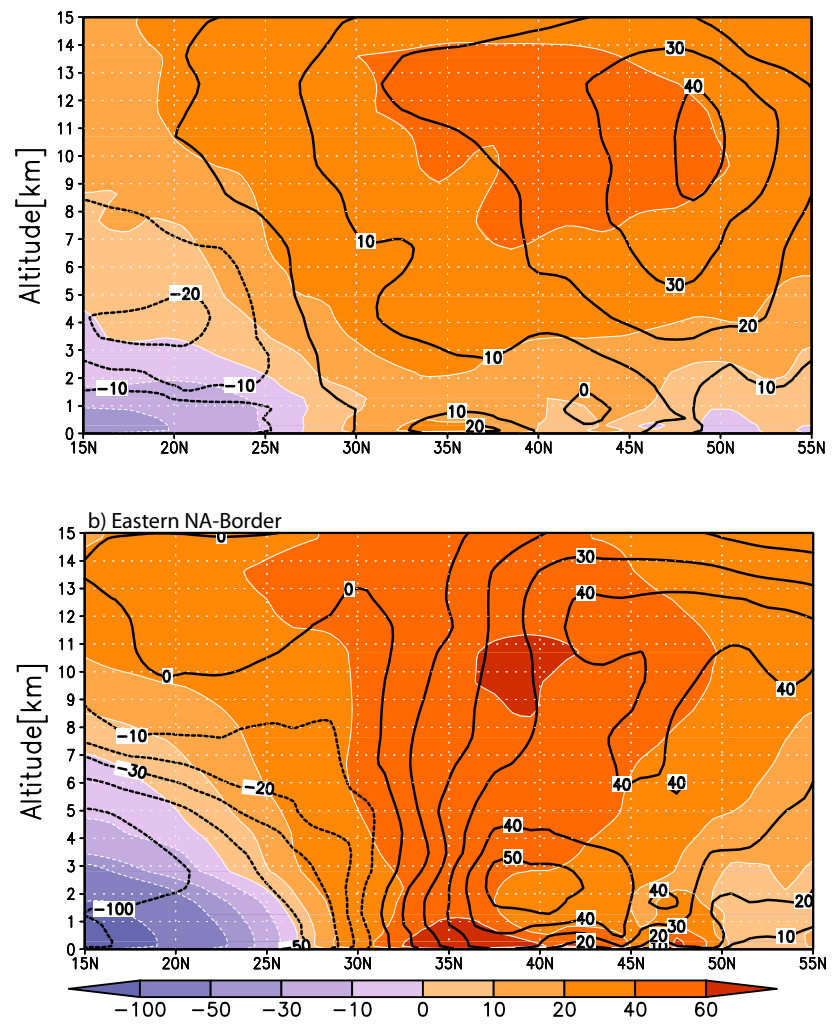

Fig. 3. Vertical sections of aerosol transport fluxes $\left(\mu \mathrm{g} \mathrm{m}^{-2} \mathrm{~s}^{-1}\right)$ at (a) the western and (b) eastern borders of NA- region seasonally averaged in winter (filled contours) and summer (contour lines) over 1995-2004.

border in July in Fig. 2 is related with the active transatlantic transport of summertime dust aerosol from Saharan. Over the EU-region covering Europe and North Africa (Table 1), at the western border south of $35^{\circ} \mathrm{N}$, the vertical heights of aerosol export flows (negative transport fluxes) into the Atlantic Ocean raise from $3 \mathrm{~km}$ in winter to $7 \mathrm{~km}$ in summer (Fig. 4a). The higher layers of summertime aerosol export in the tropospheric easterly belt favour a transatlantic transport contributing to North African aerosols. For the aerosol import at the western EU-border, the entering centers keep almost stationary in the layers of $3-5 \mathrm{~km}$ between $30^{\circ} \mathrm{N}-35^{\circ} \mathrm{N}$ from winter to summer (Fig. 4a). At the eastern EU-border, the wintertime aerosols are exported through the nearly entire area of vertical section with two centers at the height of $2-5 \mathrm{~km}$ respectively south of $30^{\circ} \mathrm{N}$ and between $38^{\circ} \mathrm{N}-$ $48^{\circ} \mathrm{N}$, providing strong aerosol outflows from the EU-region for transeurasian transport in winter (Fig. 4b). At the eastern EU-border, the summertime aerosol export in the free troposphere with a center at $8-11 \mathrm{~km}$ between $35^{\circ} \mathrm{N}$ and $45^{\circ} \mathrm{N}$ is accompanied by the aerosol outflows at $25^{\circ} \mathrm{N}-$ $30^{\circ} \mathrm{N}$ and the inflows at $30^{\circ} \mathrm{N}-45^{\circ} \mathrm{N}$ within the boundary layer below $3 \mathrm{~km}$ (Fig. 4b). Over the EA-region, it is most 

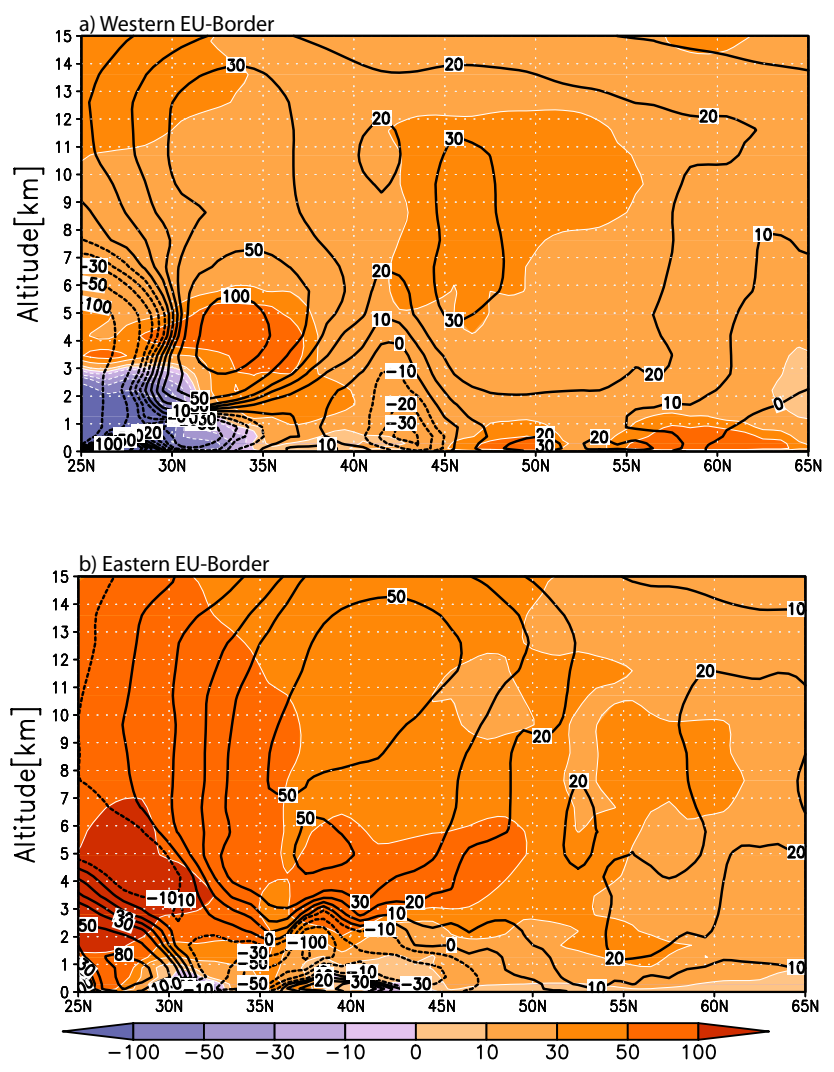

Fig. 4. Same as in Fig. 3, but for the EU-region.

notable with the eastward transboundary aerosol transport occurring in the free troposphere. The import at the western EA-border $\left(95^{\circ} \mathrm{E}\right)$ and the export at the eastern EAborder $\left(160^{\circ} \mathrm{E}\right)$ exhibit a south-north shift from winter to summer, especially with a very strong outflow at the eastern EA-border in winter for the transpacific transport of aerosols (Fig. 5a and b). Controlled by the seasonal changes of Asian monsoon circulations, the aerosol transport directions in the mid- and upper troposphere at both EA-borders south of $30^{\circ} \mathrm{N}$ reverse between winter and summer (Fig. 5a and b). Finally, over the SA-region, at the western border south of $20^{\circ} \mathrm{N}$ and at the eastern border south of $15^{\circ} \mathrm{N}$, the seasonal changes of aerosol transport follow the Asian winter (westward) and summer (eastward) monsoon winds in the lower troposphere, especially for strong transport flows within the boundary layer from surface to $3 \mathrm{~km}$ (Fig. $6 \mathrm{a}$ and b). Controlled by winter-summer evolution of westerly and easterly belts across the western and eastern SA-borders, a strong eastward transport center in winter is built between $24^{\circ} \mathrm{N}$ and $30^{\circ} \mathrm{N}$ in the mid-troposphere, and the westward transport flows in the upper troposphere extend northwards to $30^{\circ} \mathrm{N}$ in summer (Fig. 6a and b). The 10-yr averaged HTAPtransport patterns in Figs. 3-6 for winter and summer could vary year to year depending on the inter-annual variability in meteorology and aerosol emissions.
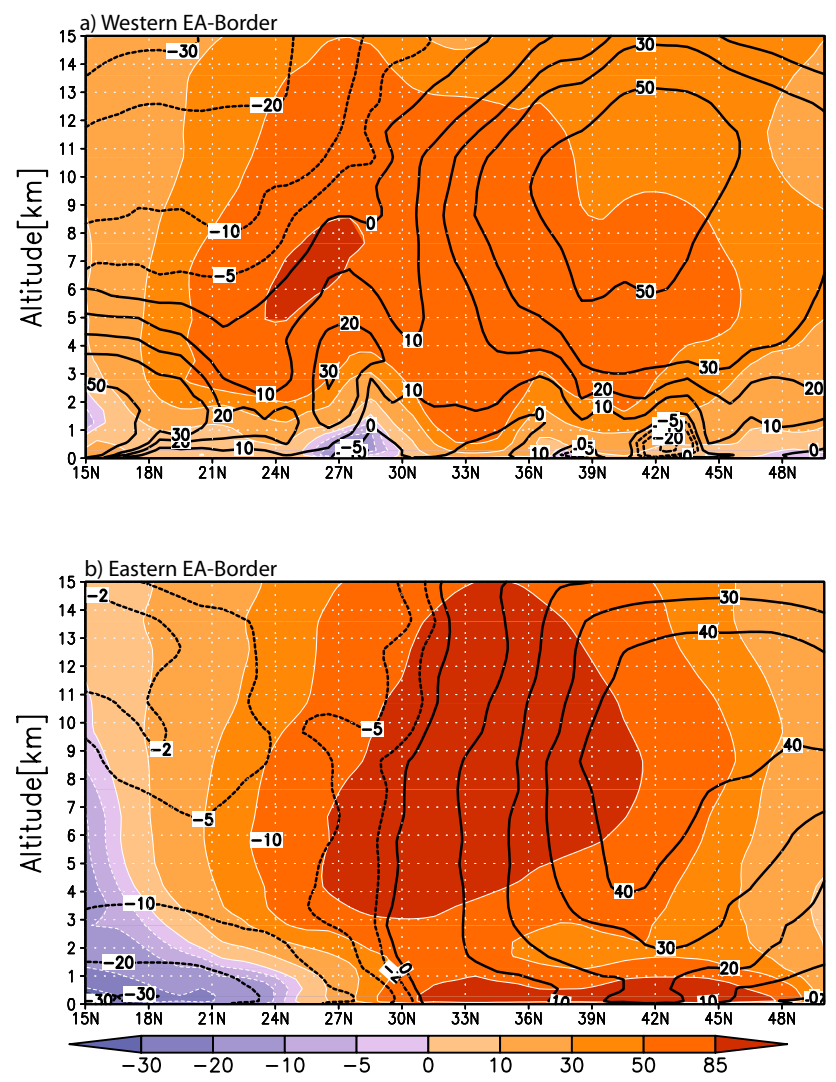

Fig. 5. Same as in Fig. 3, but for the EA-region.

\subsection{Aerosol transport patterns in the NH}

The S-R relationships across the four HTAP-regions are controlled by the intercontinental aerosol transport patterns in the NH. Using a 15-yr simulation of dispersion of carbon monoxide over 8-10 day periods, the primary intercontinental transport pathways in the NH for the HTAP are illustrated near ground level $(<3 \mathrm{~km})$ and in the atmosphere $>3 \mathrm{~km}$ (TF_HTAP, 2007; Eckhardt et al., 2003). It is also identified by a 44-yr simulated climatology of Asian dust aerosol that the regional transport of Asian dust aerosol over Asian subcontinents was entrained to an elevation of $<3 \mathrm{~km}$, and the transpacific transport peaks between 3 and $10 \mathrm{~km}$ in the troposphere (Zhao et al., 2006). Based on this model study on the hemispheric aerosol transport (Figs. 3-6), the great majority of aerosol transport is found to occur within the troposphere, and aerosol transport fluxes averaged from surface to $3 \mathrm{~km}$ for the boundary layer transport and between 3 and $10 \mathrm{~km}$ for the free tropospheric transport could be used to further describe the aerosol transport patterns in the NH (Fig. 7).

Closely associated with the general circulation in the atmosphere, especially in the NH troposphere, the hemispheric aerosol transport patterns are built up. Atmospheric circulations in the $\mathrm{NH}$ troposphere could be divided into three regimes: the low latitudes including tropics and subtropics, 

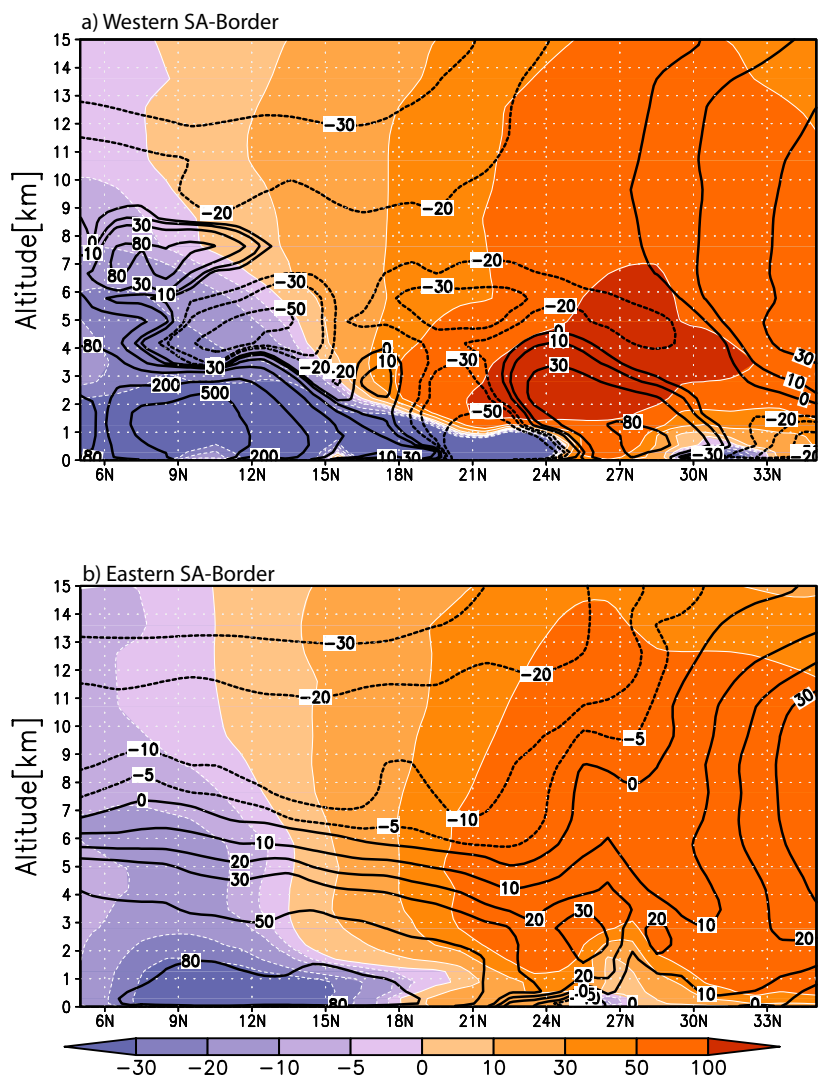

Fig. 6. Same as in Fig. 3, but for the SA-region.

the mid-latitudes $\left(30^{\circ} \mathrm{N}-60^{\circ} \mathrm{N}\right)$ and the Polar Regions. The low latitudes are dominated by easterly jet and the trade wind driving the long-range transport (LRT) from east to west. In the mid-latitudes, prevailing westerlies govern the aerosol transport along westerly wave from west to east in the troposphere. The Arctic pattern in the troposphere over the Polar Regions consists of the closed circulation systems of cyclones, anticyclones and the polar vortex, forcing the strong aerosol transport in both zonal and meridional directions. Additionally, the Asian monsoons constitute a major circulation feature in the $\mathrm{NH}$ with their anomalies causing a significant inter-annual variability in Asian aerosol emissions, depositions and transport (Gong et al., 2006; Zhang et al., 2010). The aerosol transport patterns in the NH could be characterized from the 10-yr simulated aerosol climatology as follows:

1. It is most distinct for the $\mathrm{NH}$ transport patterns that the circumpolar transport routes connecting all the EA, SA-, NA- and EU- regions are set up by the westerlies along the mid-latitudes. Playing a dominant role in the aerosol transport (Fig. 1), these intercontinental transport routes in the mid-latitude troposphere are changed from the more meridional structures in winter to the more zonal structures in summer following the seasonal evolution of trough and ridge system in the

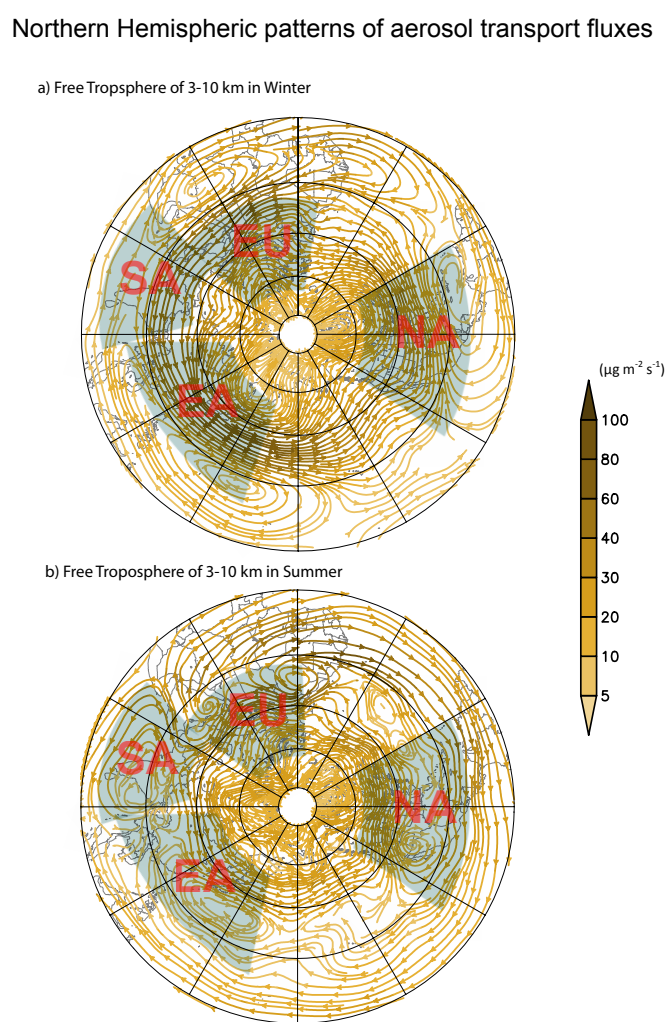

Northern Hemispheric patterns of aerosol transport fluxes c) Boundary Layer below $3 \mathrm{~km}$ in Winter

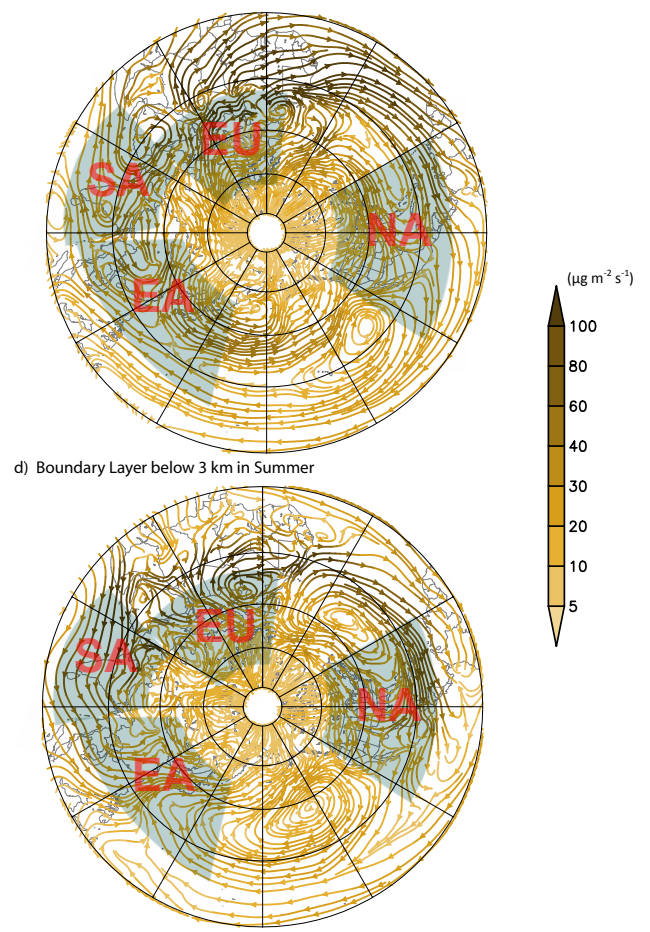

Fig. 7. Northern Hemispheric patterns of aerosol transport fluxes $\left(\mu \mathrm{g} \mathrm{m}^{-2} \mathrm{~s}^{-1}\right)$ averaged in the free troposphere between 3 to $10 \mathrm{~km}$ (a) in winter and (b) summer as well as within the boundary layer below $3 \mathrm{~km}$ (c) in winter and (d) summer over 1995-2004. The colored boxes indicate four HTAP-regions (Table 1). 
westerly wave. Corresponding with the seasonal variations of westerly belt in the $\mathrm{NH}$ troposphere, the aerosol transport jets at $30-55^{\circ} \mathrm{N}$ in winter and at $40-65^{\circ} \mathrm{N}$ in summer enhance (weaken) the transpacific (EA to NA), transatlantic (NA to EU) and transeurasian (EU to EA and EU to SA) transport of aerosols in winter (summer) (Fig. 7a and b). The high centers of the eastward transport are located over the NA-, EU- and EA-regions and their immediate downwind areas with the transport fluxes decreasing along the intercontinental pathways.

2. During summertime, the tropical and subtropical easterlies extend northwards to $30^{\circ} \mathrm{N}$ in the free troposphere accompanying the northward migration of the ITCZ or Intertropical Convergence Zone and the withdrawal of westerly zone (Fig. 7a and b). The easterly belt south of $30^{\circ} \mathrm{N}$ in the low latitudes build the westward transatlantic transport routes from the North African part of EU-region to the NA-region, the North American aerosol transport into Pacific and the aerosol transport from West Pacific to the EA-region in the free troposphere (Fig. 7b). Differently in the boundary layer below $3 \mathrm{~km}$, the westward aerosol transport over the low latitude Atlantic and Pacific Ocean from the EU- to NA-region and from the NA- to EA-region occurs not only in summer but also in winter in (Fig. 7c and d). Driven by the seasonal variations of subtropical easterlies, the westwards transatlantic (EU to NA) and transpacific (NA to EA) transport pathways in the low latitude boundary layer shift southwards with weak transport currents in winter and northwards with strong transport jets in summer (Fig. 7c and d).

3. Governed by winter and summer monsoons in South and East Asia, the aerosol transport between the SAand EA-regions in the boundary layer reverses with the northeast flows from EA- to SA-region in winter and the southwest flows from SA- to EA-region in summer (Fig. 7c and d). Along these transport pathways in the northeast and southwest flows, aerosols from EA- and SA-monsoon regions could reach into the low latitude Indian Ocean for the LRT to the Southern hemisphere in winter (Fig. 7c) and into the high latitude Pacific Ocean for the LRT to the Arctic region in summer (Fig. 7d). In the free troposphere of $3-10 \mathrm{~km}$, the aerosol transport patterns over the SA-region are featured by an anticyclonic current shear in winter and a cyclone circulation in summer (Fig. 7a and b). In winter, the SA-aerosols north of the current shear join the strong intercontinental transport in the mid-latitude westerlies, while south of that shear, the easterly aerosol transport currents pass the SA-region (Fig. 7a). The summertime cyclone circulation of aerosol transport isolates the exports of SAaerosols for the LRT but with an enhanced import from the EU-region in the free troposphere (Fig. 7b).
4. The cross-Arctic transport pathways among EU-, EAand NA-regions are created through the interactions of Arctic anticyclone, cyclone circulations, polar vortex and mid-latitude circulations (Fig. 7), especially in the winter, when the pathways for stronger cross-Arctic transport in both the boundary layer and the free troposphere is maintained by a combination of the welldeveloped trough/ridge systems in the mid-latitudes and the southwards extending circulations from the Arctic (Fig. 7a and c).

Compared the aerosol transport flux distributions in the free troposphere and within the boundary layer between Figs. 7a (7b) and 7c (7d), the stronger transport fluxes with high efficiency aerosol transport is found along the mid-latitude westerlies in the free troposphere for the eastwards transpacific, transatlantic and transeurasian aerosol transport as well as in the boundary layer for the LRT in the low latitude easterlies and the regional transport within the HTAP-regions. Considering the largest aerosol mass contributions of the eastward transport in the mid-latitudes for the hemispheric transport in Fig. 1, the aerosol transport pathways in the free troposphere built by the mid-latitude westerlies could be regarded as the most efficient transport patterns determining the S-R relationships for intercontinental aerosols.

\section{Meteorological controls in the inter-annual aerosol variability}

We established the mean climate of hemispheric aerosol transport by using the simulation data of all aerosols from both the natural and anthropogenic sources. The inter-annual variability discussed for the aerosol transport in Sect. 3 is complicated by the tempo-spatial changes of emissions and the variations of meteorology over the S-R regions and the transport pathways. The influence of meteorological factors is difficult to distinguish from simulations and observations. However, for the anthropogenic aerosols, the monthly emissions of sulphur, anthropogenic black and organic carbon aerosols are unchanged inter-annually in the 10-yr GEMAQ simulation over 1995-2004 (Gong et al., 2012), which provides a way to isolate the meteorological contributions to the inter-annual variability in the intercontinental transport of S-R air pollution through an analysis of the 10-yr anthropogenic aerosol modeling in this section.

\subsection{Inter-annual aerosol transport variability}

In Fig. 8, the CV-values are used to analyse the monthly changes of HTAP-regionally averaged aerosols for the relative magnitudes of inter-annual variability over the HTAPregions. Figure 8 presents the interannual variability magnitudes of anthropogenic aerosol surface concentrations and column loading regionally averaged over each HTAPregion with the monthly $\mathrm{CV}$-changes. Driven only by 

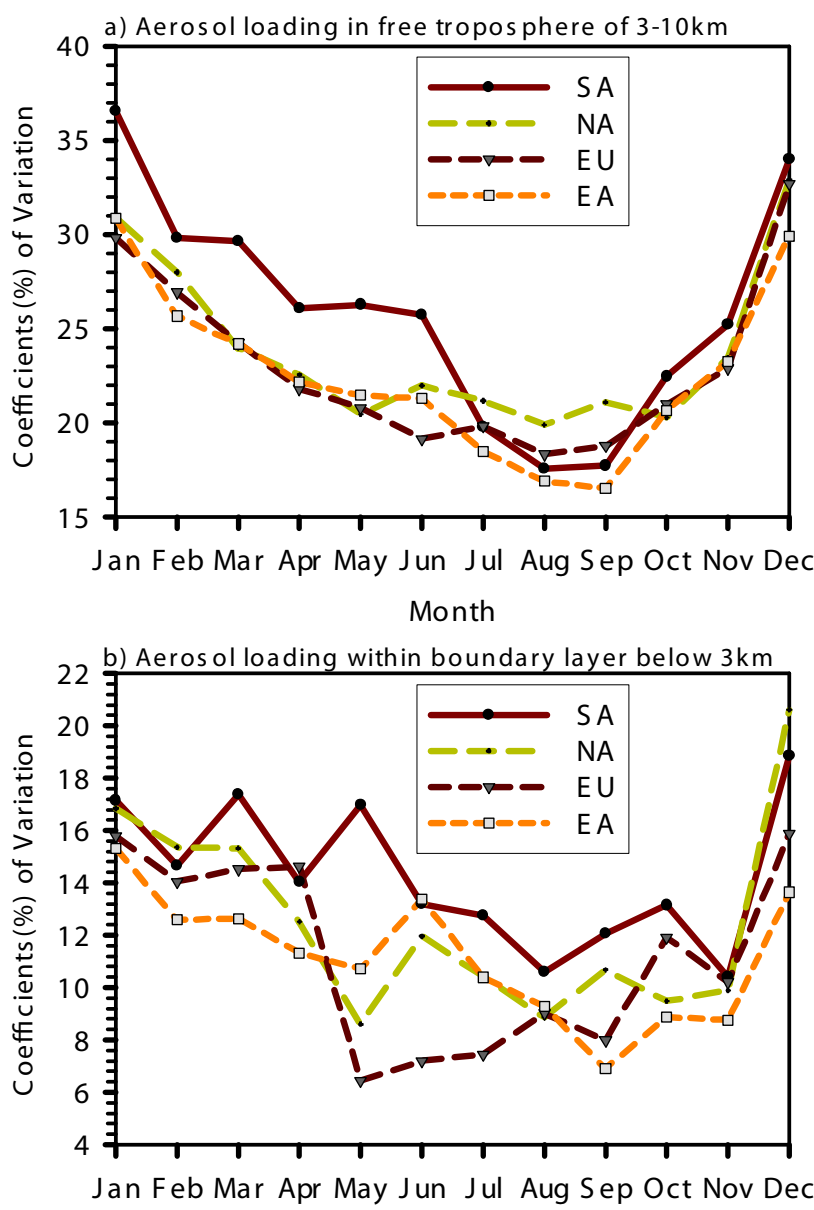

Month

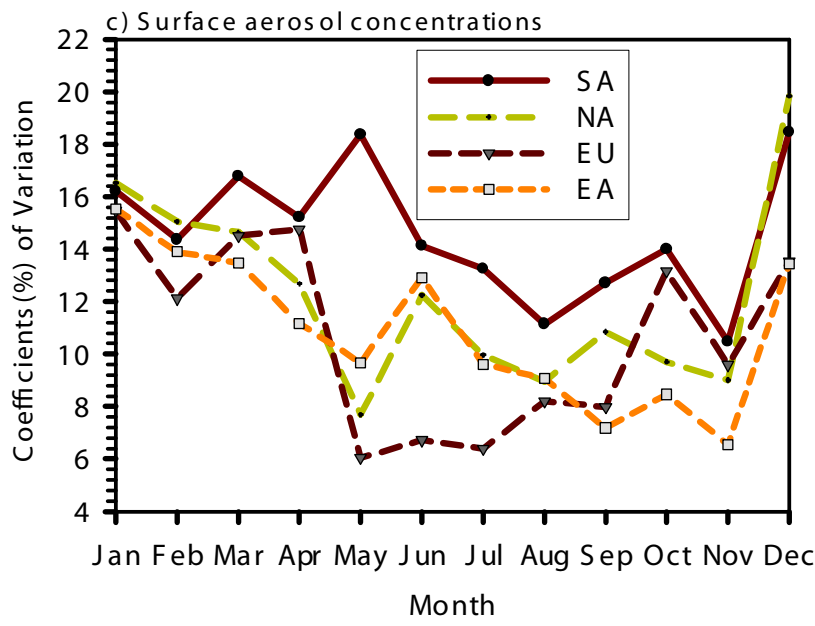

Fig. 8. Monthly CV(coefficients of variations) in the anthropogenic aerosol loading (a)in the free troposphere of 3-10 km, (b) within the boundary layer below $3 \mathrm{~km}$ and (c)the surface concentrations averaged in the SA-, NA-, EU- and EA-regions over 1995-2004. meteorological changes with the constant monthly emissions, the column loadings in the free troposphere over the HTAP regions vary from year to year with the highest magnitudes of 30-37\% in January and December and the lowest magnitudes of 16-20\% in August and September (Fig. 8a). Maintained by the mid-latitude westerly belt in the $\mathrm{NH}$, the mid-latitude pathways of intercontinental aerosol transport in the free troposphere dominate the intercontinental transport, which result in the inter-annual aerosol variability in the free troposphere and within the boundary layer with the similar patterns of monthly $\mathrm{CV}$-changes over four HTAP-regions (Fig. 8a-c). The monthly CV-values of surface aerosol concentrations and column loading in the boundary layer ranged from $6 \%$ to $20 \%$, which are about $30-70 \%$ of the monthly CV-changes in the free tropospheric aerosols. Caused by the low efficiency of aerosol transport within the boundary layer and the exchange process between the boundary layer and the free troposphere controlled by the local meteorology, the influence of meteorology on inter-annual aerosol variability is weaker within the boundary layer and more regiondependent over the HTAP-regions with the stronger controls of emission sources (Fig. 8b-c). The nearly same patterns of monthly CV-values in the boundary layer and surface in Fig. 8b-c could also be interpreted by a decisive impact of the boundary layer aerosols on the surface PM-levels in the receptor regions and a dominant role of the aerosol emissions in the boundary layer aerosols over the source regions.

An aerosol cycle for the S-R relationships can be composed of three parts: (1) emissions at the surface and consequently mixing within the boundary layer in the source regions, (2) lifting from the boundary layer to the free troposphere and subject to LRT and (3) descending into the boundary layer and contributing to the surface pollution levels at the receptor places (Colette et al., 2008). The domestic aerosols emitted from any HTAP-region primarily affect the surface aerosol concentrations as well as the column loading within the boundary layer and in the free troposphere over that region. However, due to the aerosol transport, each HTAP region can be a source as well as a receptor of aerosols. The monthly CV-values in Fig. 8 without the inter-annual emission variability could mostly be brought by the transported foreign aerosols from the aerosol sources. The monthly contributions of foreign aerosols engaging in the intercontinental transport from the upwind sources could approximately lead a range of $16-37 \%$ aerosol mass variations in the free troposphere over the downwind HTAPregions based on the $\mathrm{CV}$-values (Fig. 8a). Compared to the contributions of foreign aerosols in the free troposphere, about $30-70 \%$ of foreign aerosols reach into the boundary layer influencing the surface concentration variations in the HTAP regions (Fig. 8b-c). A 1-yr simulation of the transport of six passive tracers estimates that the domestic tracers dominate total tracer columns over all continents in the $\mathrm{NH}$ with $20 \%$ mass contributed from foreign tracers (Stohl et al., 2002a). This 10 -yr aerosol simulation could not only confirm 
a dominance of domestic aerosols from the sources over the $\mathrm{S}-\mathrm{R}$ relationships and also quantify an importance of intercontinental aerosol transport driven by meteorology over the $\mathrm{NH}$ at a more fundamental level.

It should be emphasized that the inter-annual aerosol variability presented in Fig. 8 results from the anthropogenic aerosol variations determined only by meteorological factors with excluding the inter-annual emission changes. The meteorological factors can also exert a considerable influence on the aerosol emission variations (Gong et al., 2006, 2012). As an important meteorological factor, surface winds force the natural aerosols of soil dust and sea salt to inject into the atmosphere (Gong et al., 1997, 2003). Considering the meteorological influences on aerosol emissions and the year to year changes of natural aerosol emissions, the CV-values in the Table 2 are based on the integration of inter-annual variability of natural and anthropogenic aerosols. The meteorological factors controlling the inter-annual variability of anthropogenic aerosols in Fig. 8 are further discussed in the next section.

\subsection{Meteorological factors driving the inter-annual variability}

Changes in meteorology can affect the S-R relationships for intercontinental aerosol by perturbing transport rates (wind speed, mixing and convection), precipitation scavenging and dry deposition. As designed in the model setup (Sect. 2), the monthly anthropogenic emissions in the simulation are constant without any inter-annual changes over 1995-2004. Meteorological factors explaining the year to year variations of aerosol transport could be identified from the 10-yr anthropogenic aerosol modeling results without considering the inter-annual changes in anthropogenic aerosol emissions.

As the measurement of variability, the standard deviations of annual transport fluxes are used to express the inter-annual variations of anthropogenic aerosol transport in the $\mathrm{NH}$ over 1995-2004 in Fig. 9. The distributions of standard deviations in Figs. 9 and 10 display the spatial patterns of interannual aerosol variability with the absolute magnitudes of transport fluxes, dry and wet depositions in the NH. As discussed in Sect. 3, the circumpolar aerosol transport routes connecting all the EA-, SA-, NA- and EU-regions are set up by the mid-latitude westerlies in the free troposphere with a dominant role in the aerosol transport. Along these eastward transport routes in the mid-latitudes, a zone of large interannual aerosol transport variability with the high standard deviations of transport fluxes in the free troposphere circulated with the maximums over the four HTAP-regions and immediate downwind areas (Fig. 9a). The year to year variations in aerosol transport rates in the free troposphere are controlled by the inter-annual changes in the mid-latitude circulation of westerlies. The anomalies in the mid-latitude circulation patterns of westerlies in the troposphere modulate the inter-annual variability in the intercontinental aerosol. The
Table 3. The inter-annual variations in dry and wet aerosol depositions with the standard deviations (tons $\mathrm{km}^{-2}$ ) averaged during 1995-2004 over four HTAP-regions.

\begin{tabular}{lllll}
\hline & EA-Region & NA-Region & EU-Region & SA-Region \\
\hline Dry Deposition & 0.062 & 0.049 & 0.051 & 0.064 \\
Wet Deposition & 0.191 & 0.103 & 0.137 & 0.140 \\
\hline
\end{tabular}

large transport flux centers over the four HTAP-regions and immediate downwind areas are closely associated with the aerosol uplifts from the emission sources within the boundary layer into the free troposphere. The aerosol uplifts depend on the local meteorology (mixing layer depth, convection, frontal passages et al.) in the HTAP-regions and immediate downwind areas. The inter-annual variability in the boundary layer aerosol transport fluxes is distributed with the similar patterns to those in the free troposphere, especially in the mid-latitudes (Fig. 9b). But the inter-annual changes of the mid-latitude aerosol transport rates in the free troposphere are 2-4 times higher than in the boundary layer, while the aerosol transport in the low latitude easterly belt over the Atlantic Ocean and the NA-region varies from year to year more strongly in the boundary layer than in the free troposphere (Fig. 9a-b).

As the impact of these aerosol sources on the receptor regions is alleviated with weakening transport fluxes along the intercontinental pathways, aerosol removal processes in the atmosphere influence the S-R relationships for intercontinental air pollution. Deposition is a major removal process for aerosols. In the aerosol module CAM (Gong et al., 2003a) implemented in the model GEM-AQ/EC, deposition processes include particle dry and wet depositions. For wet deposition with below-cloud and in-cloud washout processes, the precipitation process scavenging can efficiently remove aerosols from the atmosphere. Dry depositions are also determined by surface wind, moisture and other meteorological conditions in the boundary layer. Resulted from the inter-annual variability in precipitation and the meteorological conditions in the boundary layer, dry and wet depositions of aerosols fluctuate from year to year. Figure 10a and $b$ present the distribution of inter-annul variability in annual aerosol mass removed by dry and wet depositions in the NH with the standard deviations over 1995-2004. The regional averaged variations in dry and wet depositions over the HTAP-regions of EA, NA, EU and SA are shown in Table 3 . The inter-annual variability in wet deposition is larger by a factor of $2-10$ than in dry deposition over the source regions and particularly along the transport pathways. The patterns of wet deposition variability follow the transport pathway patterns in the free troposphere, especially along the major pathways in the mid-latitude westerly zone and in the low latitude easterly belt (Fig. 10a), while inter-annual variability in dry deposition is distributed in correspondence with the aerosol transport patterns in the boundary layer (Figs. 9b and 
Standard deviations of anthropogenic aerosol transport fluxes a) Free Troposphere of $3-10 \mathrm{~km}$

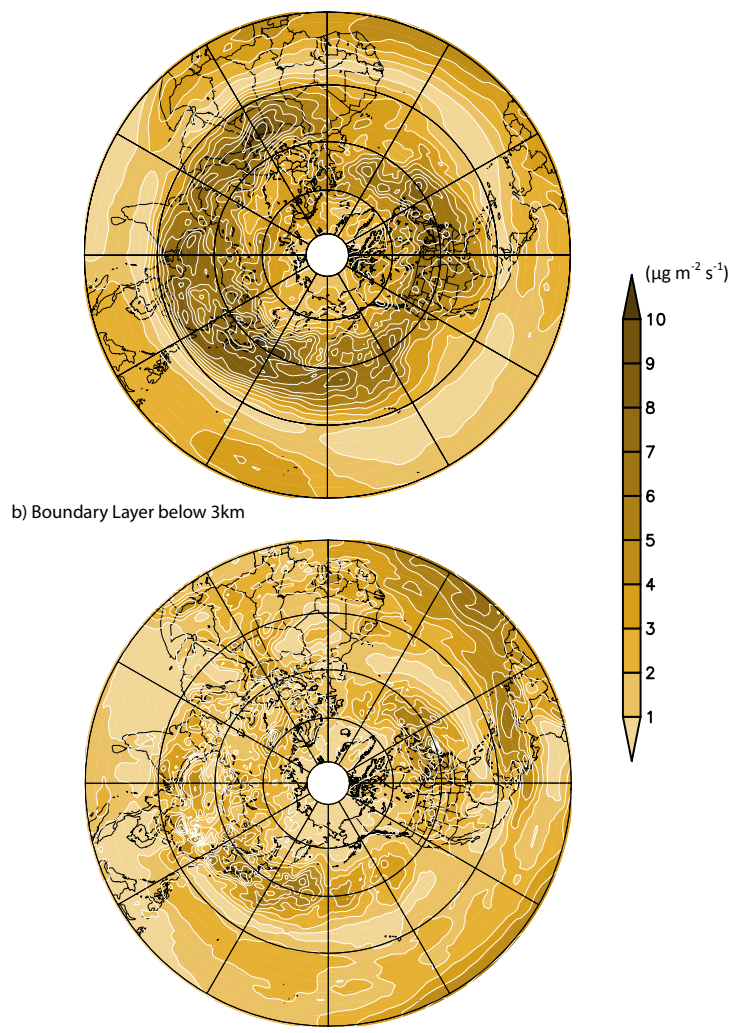

Fig. 9. Interannual variability of anthropogenic aerosol transport fluxes in the standard deviations $\left(\mu \mathrm{g} \mathrm{m}^{-2} \mathrm{~s}^{-1}\right)$ over 1995-2004 (a) in free troposphere of $3-10 \mathrm{~km}$ and (b) in boundary layer below $3 \mathrm{~km}$.

$10 \mathrm{~b})$. The variations of precipitation over the intercontinental aerosol transport pathways as well as the changes of meteorological conditions in the boundary layer are two important meteorological factors influencing the inter-annual variability in the S-R relationships for the intercontinental aerosol transport.

Based on a 44-yr simulated climatology of Asian dust aerosol and its trans-Pacific transport, it is found out that dry deposition is the major removal process for dust aerosol over the Asian deserts, while wet deposition as function of precipitation is the dominant process of dust aerosol removal over the transpacific transport pathways (Zhao et al., 2006). Unlike dust aerosol, the anthropogenic aerosols of sulphate, organic and elemental carbon in this model are mostly present as fine particles less than $2.5 \mu \mathrm{m}\left(\mathrm{PM}_{2.5}\right)$. The finer aerosols are more efficiently scavenged by precipitation processes. Wet deposition is a main atmospheric sink of aerosols on the intercontinental transport pathways in the mid-latitude westerlies even over the NA-, EU-, EA-and SA-regions. Three high centers of wet aerosol deposition variations are situated respectively on the aerosol transport pathway from the SA-

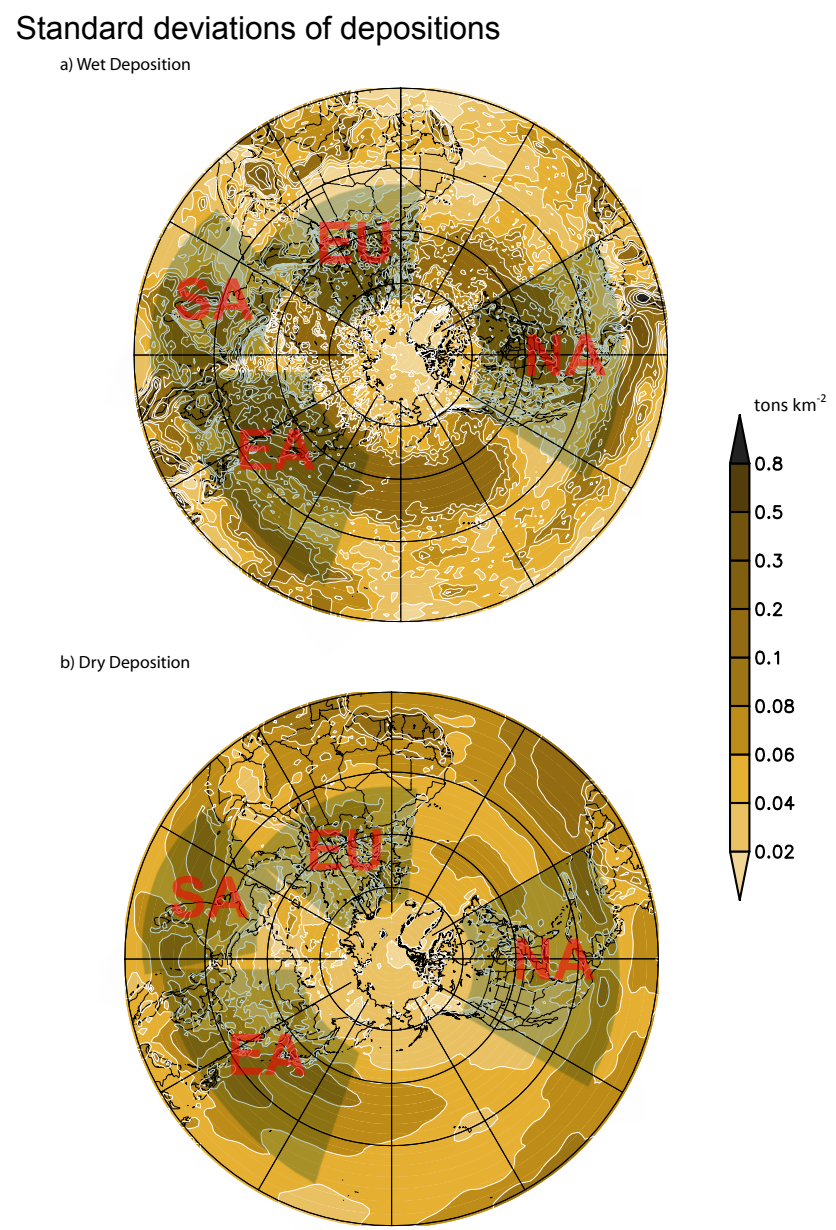

Fig. 10. Interannual variability of (a) wet and (b) dry anthropogenic aerosol depositions in the standard deviations (tons $\mathrm{km}^{-2}$ ) averaged over 1995-2004. The shaded boxes indicate four HTAP-regions (Table 1).

to EA-region as well as over two aerosol outflow areas from East Asia to Northwest Pacific and from North America to Northwest Atlantic (Fig. 10a). Over these three center areas, the high variations of wet deposition from year to year are related with the inter-annual anomalies in precipitation of Asian monsoon and storm tracks over the extratropical regions from East Asia to North Pacific and between North America and North Atlantic (Zhang et al., 2007; Ding, 1994). Dry deposition is an important aerosol sink for the aerosol transport, especially over the aerosol source regions and in the easterly belt with the dominant aerosol transport within the boundary layer in the NH (Fig. 10b).

\subsection{Connections to El Niño-Southern Oscillation (ENSO)}

It is well known that the El Niño-Southern Oscillation (ENSO) exhibits the greatest impact on the inter-annual variability of the global climate. El Niño and La Nina are 
a) Free Toposphere from 3 to $10 \mathrm{~km}$ in El Niño Years

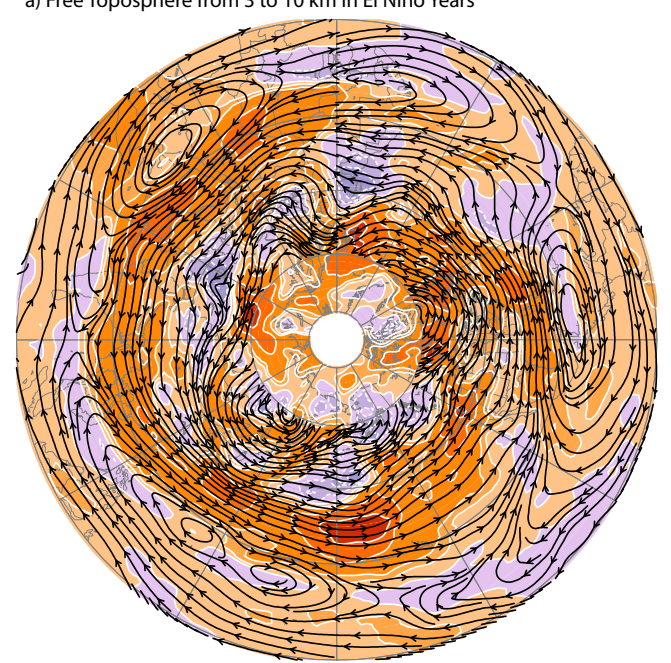

c) Boundary Layer below $3 \mathrm{~km}$ in El Niño Years

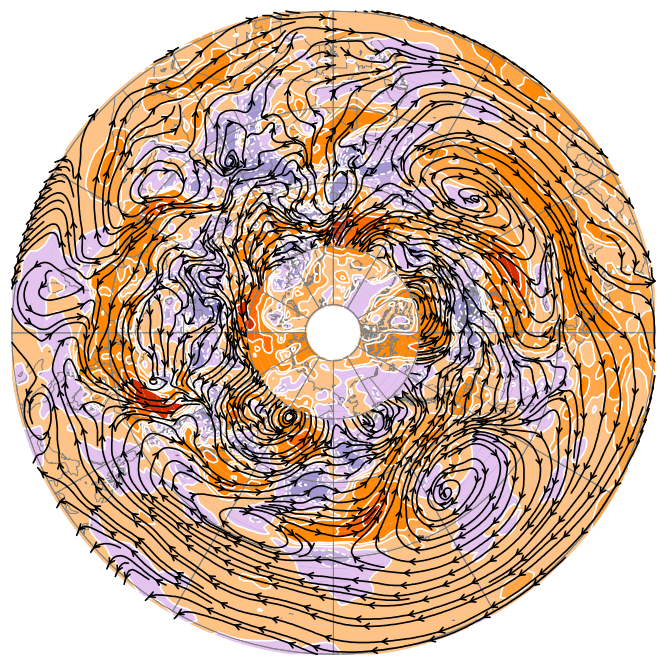

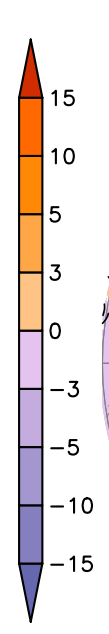

b) Free Troposphere from 3 to $10 \mathrm{~km}$ in La Niña Years

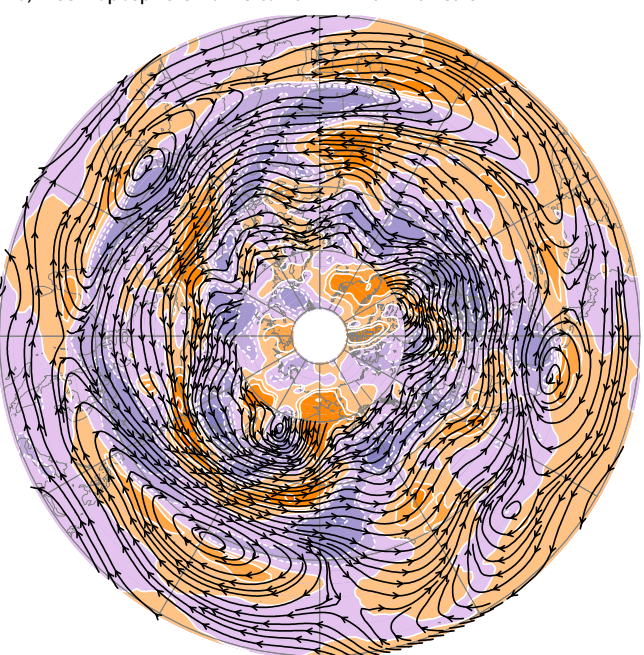

d) Boundary Layer below $3 \mathrm{~km}$ in La Niña Years
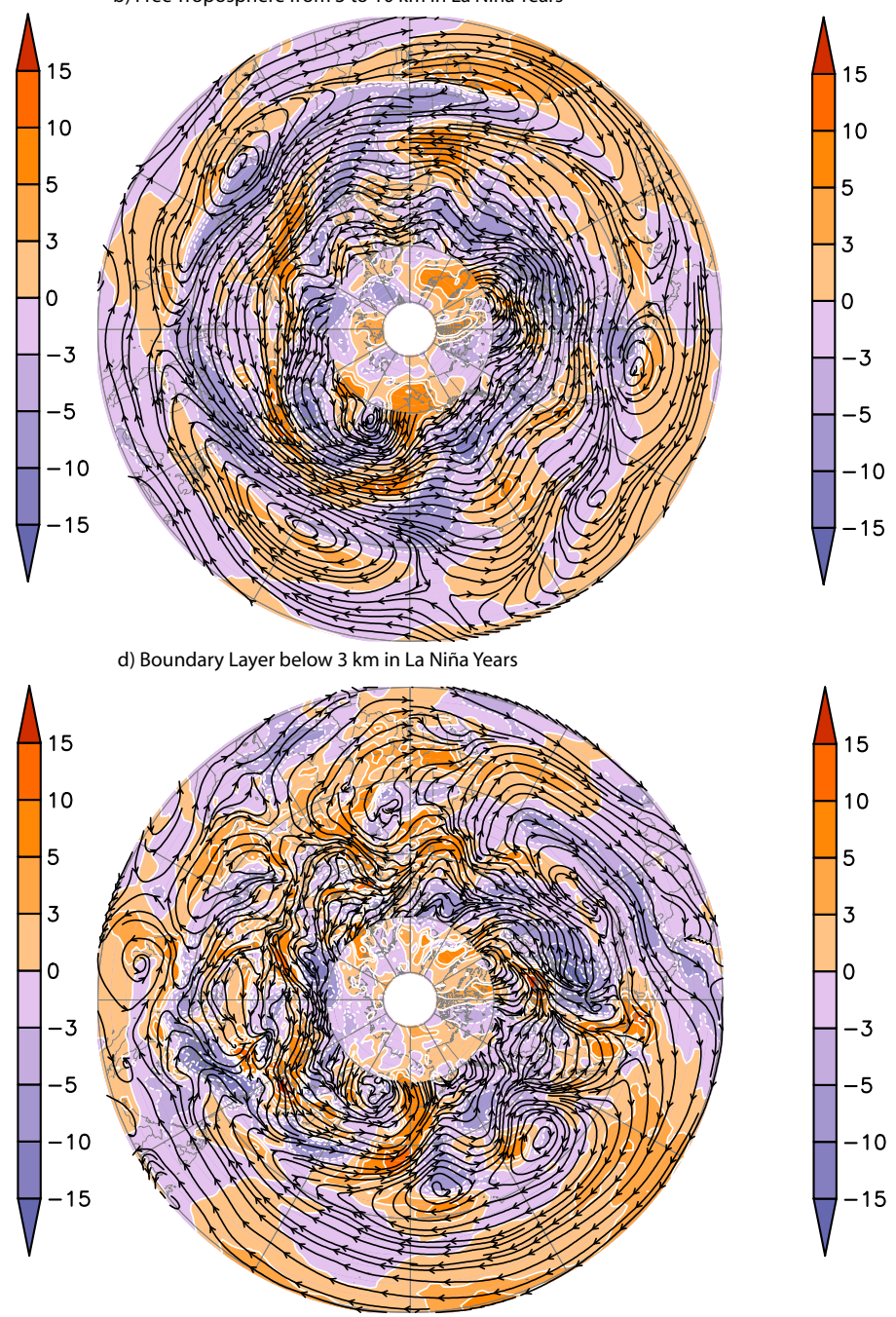

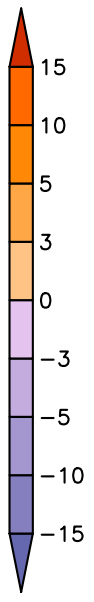

Fig. 11. Anthropogenic aerosol transport fluxes $\left(\mu \mathrm{g} \mathrm{m}^{-2} \mathrm{~s}^{-1}\right.$; streamlines) averaged in three El Niño years $(1995$, 1997 and 2003$)$ and three La Niña years (1996, 1999 and 2000) and their anomalies (contours) relative to the 10-yr mean over 1995-2004 in the free troposphere from 3 to $10 \mathrm{~km}$ and within the boundary layer below $3 \mathrm{~km}$.

opposite phases of ENSO-cycle. As the strongest climatic signal, ENSO can lead the anomalies in atmospheric circulations, cloud and precipitation. These factors, as discussed in Sects. 3.3 and 4.2, are all closely related with the intercontinental aerosol transport for the S-R relationships in the $\mathrm{NH}$. The ENSO exerts a remarkable impact on Asian dust production, deposition, regional and transpacific transport (Gong et al., 2006). A strengthening and southward shift of westerly jet over North Pacific is evident during El Niño winter. The strongest ENSO influence on the transport of Asian tracers to North America is in winter over the subtropical eastern Pacific (Liu et al., 2005).

Similarly to the inter-annual variations in aerosol concentrations and loadings shown in Fig. 8, the regional net transport fluxes, wet and dry depositions of aerosols have been analysed over four HTAP-regions. The insignificant correla- tions with the ENSO index were found for all the HTAPregional aerosol concentrations and loadings as well as the net transport fluxes, wet and dry depositions, which could be determined by the HTAP-region positions and areas (Table 1). Based on the $10 \mathrm{yr}$ GEM-AQ/EC modeling, a composite analysis of aerosol transport fluxes is performed for three typical El Niño years $(1995,1997$, and 2003) and three La Niña years (1996, 1999 and 2000) to examine the influence of ENSO on the hemispheric aerosol transport in the $\mathrm{NH}$ scale. The intercontinental transport of aerosols in the $\mathrm{NH}$ varies seasonally with a factor of 5-8 between the maximum in late winter and spring the minimum in late summer and fall (Fig. 2). Figure 11 shows the aerosol transport flux patterns averaged over three El Niño years and three La Niña years from January to May with the streamlines and their anomalies of the transport flux values to the $10 \mathrm{yr}$ mean with 
the filled contours. It could be distinguished the intercontinental aerosol transport from El Niño to La Niña years with warm and cold colours for the positive and negative anomalies in the transport flux values and the aerosol transport directions following the streamline arrows. In the free troposphere, the most significant differences between El Niño and La Niña years appear along the mid-latitude transport pathways connecting all four HTAP-regions by the westerly jet. Positive and negative anomalies of the aerosol transport in El Niño and La Niña years are found over all the circumpolar intercontinental routes for transpacific, transatlantic and transeurasian transport of aerosols in the NH scale (Fig. 11ab). It is also revealed that a strengthening and southward shift of westerly jet not only over the North Pacific but also in the entire mid-latitude westerly ozone is evident for the intercontinental aerosol transport during El Niño winter and spring. In the boundary layer, the more regional anomalies with a strong and a weak aerosol transport respectively in El Niñoand La Niña-years occurs in the subtropical NA-region, over the pathways linking the EU-, SA- to EA-region and the other mid-latitude regions, especially in the low latitude easterly belt over the Indian Ocean and between the Atlantic Ocean and North America (Fig. 11c-d). These anomalies in the aerosol transport largely reflect the influence of ENSO on the inter-annual variability in intercontinental aerosol transport in the $\mathrm{NH}$.

\section{Summary and discussion}

Based on a 10-yr model simulation, a mean climate of hemispheric aerosol transport with the seasonal variations and inter-annual variability in the $\mathrm{NH}$ was studied, and the meteorological influence on the year to year variations of aerosol transport was identified in a more comprehensive understanding of the intercontinental transport of S-R air pollutants.

The intercontinental aerosol transport is dominant in the eastward direction for all the EA-, NA-, EU- and SA-regions, and the transport in the meridional direction is $0.5-2$ orders of magnitude weaker but with more significant interannual variability. The eastward transport across the low latitude SA-region is 2-4 times less compared to the midlatitude EA-, NA- and EU-regions. The intercontinental aerosol transport is found to vary seasonally with a factor of 5-8 between the peak in late winter and spring (particularly in March and April) and the low in late summer and fall (particularly in July and September).

The intercontinental transport pathways are built by the atmospheric circulations in the $\mathrm{NH}$ with the four patterns: (1) the circumpolar transport routes connecting all the EA-, SA-, NA- and EU- regions by the mid-latitude westerly zone with the transport jets at $30-55^{\circ} \mathrm{N}$ in winter and at $40-65^{\circ} \mathrm{N}$ in summer. (2) The westward transport pathways in the lowlatitude easterly belt with the westward transatlantic trans- port, the North American aerosol transport into Pacific and the aerosol transport from West Pacific to East Asia. These transport pathways move southwards with weak transport currents in winter and northwards with strong transport jets in summer. (3) The transport pathways driven by the Asian monsoons with the northeast flows from EA- to SA-region in winter and the southwest flows from SA- to EA-region in summer. (4) The cross-Arctic transport pathways among EU-, EA- and NA-regions, especially in winter.

The overall importance of hemispheric transport for aerosols for a specific region was not the purpose of this study as this has been done through a series of sensitivity studies of emission reductions organized by HTAP (HTAP, 2010). This paper is to characterize the importance of meteorology in the inter-annual variations of hemispheric aerosol transports by using a fixed emission but multiple-yr simulations. In a sense, this paper extends and supplements the HTAP study, which only used the results of one year simulation.

Driven only by meteorological variations, the column loadings in the free troposphere over the HTAP-regions interannually change with the highest magnitudes of $30-37 \%$ in January and December and the lowest magnitudes of 16 $20 \%$ in August and September. Caused by the lower transport efficiency within the boundary layer and the exchange process between the boundary layer and the free troposphere controlled by the local meteorology, the variations in the surface aerosol concentrations and column loading in the boundary layer are $30-70 \%$ of the aerosol variability in the free troposphere, which could reflect the overall importance of meteorology for the hemispheric aerosol transport.

Three meteorological factors controlling the inter-annual variations in the intercontinental aerosol transport are identified by modeling results as follows: (1) Anomalies in the mid-latitude circulation patterns of westerlies in the free troposphere. The mid-latitude transport routes in the mid-latitude westerly zone climatologically play a dominant role in the hemispheric aerosol transport. The inter-annual changes of the mid-latitude transport in the free troposphere are 2-3 time higher than in the boundary layer. (2) Variations of precipitation over the intercontinental transport pathways. The precipitation scavenging can efficiently remove aerosols from the atmosphere. The inter-annual variability is stronger in wet deposition by a factor of 2-10 than in dry deposition. The patterns of wet deposition variability follow the major transport pathways in the free troposphere and (3) Changes of meteorological conditions in the boundary layer. Dry depositions are determined by surface wind, moisture and meteorological conditions in boundary layer.

The ENSO, as a well-known source of interannual meteorological variability in the global scale, is found to be closely associated with the strong and weak mid-latitude S-R transport of aerosols respectively in El Niño- and La Niña-years. In the free troposphere, a strengthening and southward shift of westerly jet not only over the North Pacific but also in the 
entire mid-latitude westerly ozone is evident for the hemispheric aerosol transport during El Niño winter and spring; In the boundary layer, the anomalies with a strong aerosol transport in El Niño-yrs and a weak transport in Niña-years appear more regionally in the mid-latitudes and the low latitude easterly belt. The inter-annual variability in the S-R relationships has relation to ENSO-influences on the intercontinental aerosol transport anomalies.

Based on our modeling results, there are the different features for different aerosol types due to the different sources, lifetimes, regional and seasonal characterics. In this study on hemispheric aerosol transport, we analyzed the transport flux and mass for all simulated aerosols of sulfate, soil dust and sea salt as well as organic carbon and black carbon from both natural and anthropogenic emission sources to construct a mean HTAP-climate with the seasonal and inter-annual variability and the transport patterns. The results presented here could be dominated by a single type of aerosol depending on its tempo-spatial changes with the uncertainties involved, particularly regarding possible biases associated with the location of sources within particular regions. 7 aerosol species (sea salt, soil dust, sulphate, natural and anthropogenic black/organic carbon) are simulated with the GEM-AQ/EC. Focusing on the transport of all modeled aerosols and meteorological influence for the HTAP, we presented the natural and anthropogenic aerosol transport patterns in the hemispheric scale. The transport feature for each aerosol type could be further studied on the 10-yr modeling with the aerosol budget for intercontinental transport in further work.

Acknowledgements. The authors wish to thank CFCAS (The Canadian Foundation for Climate and Atmospheric Sciences) for its partial financial support for this research through the NW AQ MAQNet Grant. This research was also partially supported by the National Key Research Project (2011CB403404) of the Ministry of Science and Technology of China and the Research Starting Project of NUIST (20110304) of China.

Edited by: Q. Fu

\section{References}

Anenberg, S. C., West, J. J., Fiore, A. M., Jaffe, D. A., Prather, M. J., Bergmann, D., Cuvelier, K., Dentener, F. J., Duncan, B. N., Gauss, M., Hess, P., Jonson, J. E., Lupu, A., MacKenzie, I. A., Marmer, E., Park, R. J., Sanderson, M. G.,, Schultz, M., Shindell, D. T., Szopa, S., Vivanco, M. G., Wild, O., and Zeng, G.: Intercontinental Impacts of Ozone Pollution on Human Mortality, Environ. Sci. Technol., 43, 6482-6487, doi:6410.1021/es900518z, 2009.

Chin, M., Diehl, T., Ginoux, P., and Malm, W.: Intercontinental transport of pollution and dust aerosols: implications for regional air quality, Atmos. Chem. Phys., 7, 5501-5517, doi:10.5194/acp7-5501-2007, 2007.
Colette, A., Menut, L., Haeffelin, M., and Morille, Y.: Impact of the transport of aerosols from the free troposphere towards the boundary layer on the air quality in the Paris area, Atmos. Environ., 42, 390-402, 2008.

Côté, J., Gravel, S., M'ethot, A., Patoine, A., Roch, M., and Staniforth, A.: The operational CMC-MRB Global Environmental Multiscale (GEM) model: Part I - Design considerations and formulation, Mon. Weather Rev., 126, 1373-1395, 1998.

Creilson, J. K., Fishman, J., and Wozniak, A. E.: Intercontinental transport of tropospheric ozone: a study of its seasonal variability across the North Atlantic utilizing tropospheric ozone residuals and its relationship to the North Atlantic Oscillation, Atmos. Chem. Phys., 3, 2053-2066, doi:10.5194/acp-3-2053-2003, 2003.

Ding, Y. H.: Monsoons over China, Kluwer Academic Publishers, Dordrecht/Boston/London, 1-290, 1994.

Eckhardt, S., Stohl, A., Beirle, S., Spichtinger, N., James, P., Forster, C., Junker, C., Wagner, T., Platt, U., and Jennings, S. G.: The North Atlantic Oscillation controls air pollution transport to the Arctic, Atmos. Chem. Phys., 3, 1769-1778, doi:10.5194/acp-31769-2003, 2003.

Fiore, A. M., Dentener, F. J., Wild, O., Cuvelier, C., Schultz, M. G., Hess, P., Textor, C., Schulz, M., Doherty, R. M., Horowitz, L. W., MacKenzie, I. A., Sanderson, M. G., Shindell, D. T., Stevenson, D. S., Szopa, S., Van Dingenen, R., Zeng, G., Atherton, C., Bergmann, D., Bey, I., Carmichael, G., Collins, W. J., Duncan, B. N., Faluvegi, G., Folberth, G., Gauss, M., Gong, S. L, Hauglustaine, D., Holloway, T., Isaksen, I. S. A., Jacob, D. J., Jonson, J. E., Kaminski, J. W., Keating, T. J., Lupu, A., Marmer, E., Montanaro, V., Park, R. J., Pitari, G., Pringle, K. J., Pyle, J. A., Schroeder, S., Vivanco, M. G., Wind, P., Wojcik, G., Wu, S., and Zuber, A.: Multimodel estimates of intercontinental sourcereceptor relationships for ozone pollution, J. Geophys. Res., 114, D04301, doi:04310.01029/02008JD010816, 2009.

Gong, S. L., Barrie, L. A., and Blanchet, J.-P.: Modeling sea-salt aerosols in the atmosphere - Part 1: Model development, J. Geophys. Res., 102, 3805-3818, 1997.

Gong, S. L., Barrie, L. A., Blanchet, J.-P., Salzen, K. v., Lohmann, U., Lesins, G., Spacek, L., Zhang, L. M., Girard, E., Lin, H., Leaitch, R., Leighton, H., Chylek, P., and Huang, P.: Canadian Aerosol Module: A size-segregated simulation of atmospheric aerosol processes for climate and air quality models 1. Module development, J. Geophys. Res., 108, 4007, doi:4010.1029/2001JD002002, 2003a.

Gong, S. L., Zhang, X. Y., Zhao, T. L., McKendry, I. G., Jaffe, D. A., and Lu, N. M.: Characterization Of Soil Dust Distributions In China And Its Transport During ACE-ASIA 2. Model Simulation and Validation, J. Geophys. Res., 108, 4262, doi:4210.1029/2002JD002633, 2003b.

Gong, S. L., Zhang, X. Y., Zhao, T. L., Zhang, X. B., Barrie, L. A., McKendry, I. G., and Zhao, C. S.: A simulated climatology of Asian dust aerosol and its trans-Pacific transport. Part II: Interannual variability and climate connections, J. Climate, 19, 104122, 2006.

Gong, S. L., Zhao, T. L., Sharma, S., Toom-Sauntry, D., Lavoué, D., Zhang, X. B., Leaitch, W. R., and Barrie, L. A.: Identification of trends and interannual variability of sulfate and black carbon in the Canadian High Arctic: 1981-2007, J. Geophys. Res., 115, D07305, doi:07310.01029/02009JD012943, 2010. 
Gong, S. L., Lavoue, D., Zhao, T. L., Huang, P., and Kaminski, J. W.: GEM-AQ/EC, an on-line global multiscale chemical weather modelling system: model development and evaluations of global aerosol climatology, Atmos. Chem. Phys. Discuss., 12, 92839330, doi:10.5194/acpd-12-9283-2012, 2012.

HTAP: Hemispheric transport of air pollution 2010, United Nations, New York and Geneva, 2010.

Huang, P., Gong, S. L., Zhao, T. L., Neary, L., and Barrie, L. A.: GEM/POPs: a global 3-D dynamic model for semi-volatile persistent organic pollutants \&ndash; Part 2: Global transports and budgets of PCBs, Atmos. Chem. Phys., 7, 4015-4025, doi:10.5194/acp-7-4015-2007, 2007.

IPCC: Climate Change 2007: The Physical Science Basis. Contribution of Working Group I to the Fourth Assessment Report of the Intergovernmental Panel on Climate Change, edited by: Solomon, S., Qin, D., Manning, M., Chen, Z., Marquis, M., Averyt, K. B., Tignor, M., and Miller, H. L., Cambridge University Press, Cambridge, UK and NY, NY, 2007.

Jaffe, D., McKendry, I., Anderson, T., and Price, H.: Six "new" episodes of trans-Pacific transport of air pollutants, Atmos. Environ., 37, 391-404, 2003.

Jaffe, D. A., Anderson, T., Covert, D., Kotchenruther, R., Trost, B., Danielson, J., Simpson, W., Berntsen, T., Karlsdottir, S., Blake, D., Harris, J., Carmichael, G., and Uno, I.: Transport of Asian air pollution to North America, Geophys. Res. Lett., 26, 711-714, doi:10.1029/1999GL900100, 1999.

Jones, C., Mahowald, N., and Luo, C.: The Role of Easterly Waves on African Desert Dust Transport, J. Climate, 16, 3617-3628, 2003.

Lelieveld, J., Crutzen, P. J., Ramanathan, V., Andreae, M. O., Brenninkmeijer, C. A. M., Campos, T., Cass, G. R., Dickerson, R. R., Fischer, H.,de Gouw, J. A., Hansel, A., Jefferson, A., Kley, D., de Laat, A. T. J., Lal, S., Lawrence, M. G., Lobert, J. M., MayolBracero, O. L., Mitra, A. P., Novakov, T., Oltmans, S. J., Prather, K. A., Reiner, T., Rodhe, H., Scheeren, H. A., Sikka, D., and Williams, J.: The Indian Ocean Experiment: Widespread air pollution from South and Southeast Asia, Science, 291, 1031-1036, 2001.

Li, Q., Jacob, D. J., Bey, I., Palmer, P. I., Duncan, B. N., Field, B. D., Martin, R. V., Fiore, A. M., Yantosca, R. M., Parrish, D. D., Simmonds, P. G., and Oltmans, S. J.: Transatlantic transport of pollution and its effects on surface ozone in Europe and North America, J. Geophys. Res., 107, 4166, doi:10.1029/2001JD001422, 2002.

Liu, J., Mauzerall, D. L., and Horowitz, L. W.: Analysis of seasonal and interannual variability in transpacific transport, J. Geophys. Res., 110, D04302, doi:04310.01029/02004JD005207, 2005.

Liu, J., Mauzerall, D. L., and Horowitz, L. W.: Source-receptor relationships between East Asian sulfur dioxide emissions and Northern Hemisphere sulfate concentrations, Atmos. Chem. Phys., 8, 3721-3733, doi:10.5194/acp-8-3721-2008, 2008.

Liu, J. F., Mauzerall, D. L., Horowitz, L. W., Ginoux, P., and Fiore, A.: Evaluating intercontinental transport of fine aerosols: (1) methodology, global aerosol distribution and optical depth, Atmos. Environ., 43, 4327-4338, doi:10.1016/j.atmosenv.2009.03.054, 2009.

Olivier, J. G. J., Bouwman, A. F., van der Maas, C. W. M., Berdowski, J. J. M., Veldt, C., Bloos, J. P. J., Visschedijk, A. J. H., Zandveld, P. Y. J., and Haverlag, J. L.: Description of
EDGAR version 2.0: A set of global emission inventories of greenhouse gases and ozone-depleting 30 substances for all anthropogenic and most natural sources on a per country basis and on a $1 \times 1$ degree grid, RIVM report 771060 002/TNO-MEP report R96/119, Tech. rep., National Institute of Public Health and the Environment, Bilthoven, The Netherlands, 1996.

Osborn, T. J.: Recent variations in the winter North Atlantic Oscillation, Weather, 61, 353-355, doi:10.1256/wea.190.06., 2006.

Parrish, D. D., Holloway, J. S., Trainer, M., Murphy, P. C., Fehsenfeld, F. C., and Forbes, G. L.: Export of North American Ozone Pollution to the North Atlantic Ocean Science, 259, 1436-1439, doi:1410.1126/science.1259.5100.1436, 1993.

Prospero, J. M., Ginoux, P., Torres, O., Nicholson, S. E., and Gill, T. E.: Environmental characterization of global sources of atmospheric soil dust identified with the Nimbus 7 Total Ozone Mapping Spectrometer (TOMS) absorbing aerosol product, Rev. Geophys., 40 1002, doi:1010.1029/2000RG000095, 2002.

Ramanathan, V., and Crutzen, P. J.: New directions: Atmospheric brown clouds, Atmos. Environ., 37, 4033-4035, 2003.

Sanderson, M. G., Dentener, F. J., Fiore, A. M., Cuvelier, C., Keating, T. J., A. Zuber, Atherton, C. S., Bergmann, D. J., Diehl, T., Doherty, R. M., Duncan, B. N., Hess, P., Horowitz, L. W., Jacob, D. J., Jonson, J.-E., Kaminski, J. W., A. Lupu, MacKenzie, I. A., Mancini, E., Marmer, E., Park, R., Pitari, G., Prather, M. J., Pringle, K. J., Schroeder, S., Schultz, M. G., Shindell, D. T., Szopa, S., O. Wild, and Wind11, P.: A multi-model study of the hemispheric transport and deposition of oxidised nitrogen, Geophys. Res. Lett., 35, L17815, doi:10.1029/2008GL035389, 2008.

Schepanski, K., Tegen, I., and Macke, A.: Saharan dust transport and deposition towards the tropical northern Atlantic, Atmos. Chem. Phys., 9, 1173-1189, doi:10.5194/acp-9-1173-2009, 2009.

Seibert, P. and Frank, A.: Source-receptor matrix calculation with a Lagrangian particle dispersion model in backward mode, Atmos. Chem. Phys., 4, 51-63, doi:10.5194/acp-4-51-2004, 2004.

Sharma, S., E. Andrews, L. A. Barrie, J. A. Ogren, and D. Lavoué, Variations and sources of the equivalent black carbon in the high Arctic revealed by long-term observations at Alert and Barrow: 1989-2003, J. Geophys. Res., 111, D14208, doi:10.1029/2005JD006581, 2006

Shindell, D. T., Shindell, D. T., Chin, M., Dentener, F., Doherty, R. M., Faluvegi, G., Fiore, A. M., Hess, P., Koch, D. M., MacKenzie, I. A., Sanderson, M. G., Schultz, M. G., Schulz, M., Stevenson, D. S., Teich, H., Textor, C., Wild, O., Bergmann, D. J., Bey, I., Bian, H., Cuvelier, C., Duncan, B. N., Folberth, G., Horowitz, L. W., Jonson, J., Kaminski, J. W., Marmer, E., Park, R., Pringle, K. J., Schroeder, S., Szopa, S., Takemura, T., Zeng, G., Keating, T. J., and Zuber, A.: A multi-model assessment of pollution transport to the Arctic, Atmos. Chem. Phys., 8, 5353-5372, doi:10.5194/acp-8-5353-2008, 2008.

Stohl, A. and Eckhardt, S.: Intercontinental Transport of Air Pollution: An Introduction, in Intercontinental Transport of Air Pollution, edited by A. Stohl, Spring, Berlin, Germany, 2004.

Stohl, A., Eckhardt, S., Forster, C., James, P., and Spichtinger, N.: On the pathways and timescales of intercontinental air pollution transport, J. Geophys. Res., 107, 4684, doi:4610.1029/2001JD001396, 2002a.

Stohl, A., Trainer, M., Ryerson, T. B., Holloway, J. S., and Parrish, D. D.: Export of $\mathrm{NO}_{\mathrm{y}}$ from the North American boundary layer 
during 1996 and 1997 North Atlantic Regional Experiments, J. Geophys. Res., 107, 4131, doi:10.1029/2001JD000519, $2002 \mathrm{~b}$.

TF_HTAP: Hemispheric Transport of Air Pollution 2007, Economic Comission for Europe, United Nations, New York and Geneva, 2007.

van der Werf, G. R., Randerson, J. T., Giglio, L., Collatz, G. J., Kasibhatla, P. S., and Arellano Jr., A. F.: Interannual variability in global biomass burning emissions from 1997 to 2004, Atmos. Chem. Phys., 6, 3423-3441, doi:10.5194/acp-6-3423-2006, 2006.

VanCuren, R. A.: Asian aerosols in North America: Extracting the chemical composition and mass concentration of the Asian continental aerosol plume from long-term aerosol records in the western United States, J. Geophys. Res., 108 4623, doi:4610.1029/2003JD003459, 2003.

Venkatram, A., Karamchandani, P. K., and Misra, P. K.: Testing a comprehensive acid deposition model, Atmos. Environ., 22, 737-747, 1988.

Voulgarakis, A., Savage, N. H., Wild, O., Braesicke, P., Young, P. J., Carver, G. D., and Pyle, J. A.: Interannual variability of tropospheric composition: the influence of changes in emissions, meteorology and clouds, Atmos. Chem. Phys., 10, 2491-2506, doi:10.5194/acp-10-2491-2010, 2010.

Wilkening, K. E., Barrie, L. A., and Engle, M.: Trans-Pacific air pollution, Science, 290, 65-67, 2000.

Wu, S., Duncan, B. N., Jacob, D. J., Fiore, A. M., and Wild, O.: Chemical nonlinearities in relating intercontinental ozone pollution to anthropogenic emissions, Geophys. Res. Lett., 36, L05806, doi:05810.01029/02008GL036607, 2009.
Yu, H., Remer, L. A., Chin, M., Bian, H., Kleidman, R. G., and Diehl, T.: A satellite based assessment of transpacific transport of pollution aerosol, J. Geophys. Res., 113, D14S12, doi:10.1029/2007JD009349, 2008.

Zhang, L., Jacob, D. J., Boersma, K. F., Jaffe, D. A., Olson, J. R., Bowman, K. W., Worden, J. R., Thompson, A. M., Avery, M. A., Cohen, R. C., Dibb, J. E., Flock, F. M., Fuelberg, H. E., Huey, L. G., McMillan, W. W., Singh, H. B., and Weinheimer, A. J.: Transpacific transport of ozone pollution and the effect of recent Asian emission increases on air quality in North America: an integrated analysis using satellite, aircraft, ozonesonde, and surface observations, Atmos. Chem. Phys., 8, 6117-6136, doi:10.5194/acp-8-6117-2008, 2008.

Zhang, L., Liao, H., and Li, J.: Impacts of Asian summer monsoon on seasonal and interannual variations of aerosols over eastern China, J. Geophys. Res., 115, D00K05, doi:10.1029/2009JD012299, 2010.

Zhang, R., Li, G., Fan, J., Wu, D. L., and Molina, M. J.: Intensification of Pacific storm track linked to Asian pollution, Proc Natl Acad Sci U S A., 104(13): 5295-5299., doi:10.1073/pnas.0700618104, 2007.

Zhao, T. L., Gong, S. L., Zhang, X. Y., Blanchet, J.-P., McKendry, I. G., and Zhou, Z. J.: A Simulated Climatology of Asian Dust Aerosol and Its Trans-Pacific Transport. Part I: Mean Climate and Validation, Journal of Climate, 19, 88-103,2006.

Zhao, T. L., Gong, S. L., Zhang, X. Y., and Jaffe, D. A.: Asian dust storm influence on North American ambient PM levels: observational evidence and controlling factors, Atmos. Chem. Phys., 8, 2717-2728, doi:10.5194/acp-8-2717-2008, 2008. 